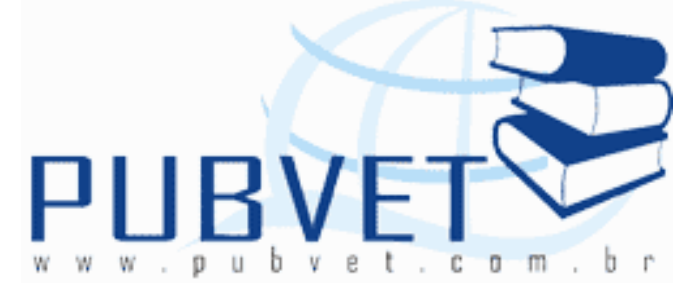

PUBVET, Publicações em Medicina Veterinária e Zootecnia.

Revisão da literatura: mineralização e perfil metabólico em ovinos

\title{
Vanessa Veronese Ortunho
}

Docente da Universidade Estadual Paulista "Júlio de Mesquita Filho" Campus Ilha Solteira, Departamento de Biologia e Zootecnia e-mail: vanessaverort@yahoo.com.br

\section{Resumo}

A ovinocultura é uma atividade que vem crescendo nos últimos anos, porém na literatura são poucas as pesquisas que reúnem dados sanguíneos e que reúnem dados sobre a mineralização destes animais, tanto com minerais orgânicos e quelatados. Baseado nisso foi feito um levantamento com os trabalhos mais atuais sobre mineralização, balanço energético negativo e estudo de perfil metabólico de animais em diferentes fases reprodutivas e produtivas desta espécie, o que originou esta revisão da literatura.

Palavras-chave: ovelhas, nutrição, sangue.

\section{Literature review: mineralization and metabolic profile in sheep}

\begin{abstract}
The sheep industry is an activity that has been growing in recent years, but in the literature there are few researches that studies blood values and mineralization of these animals, with chelates or inorganic minerals. Based on
\end{abstract}


that, was done a literature review with the most current mineralization negative energy balance and metabolic profile study of animals at different stages of reproductive and productive this species.

Keywords: blood, nutrition, sheep.

\section{INTRODUÇÃO}

Produzir a quantidade de alimento suficiente para uma população estimada em 9 bilhões de pessoas em 2050, e ao mesmo tempo preservar a natureza são os grandes desafios da agricultura e da pecuária mundial deste século. Na avaliação de representantes do agronegócio brasileiro, é importante que estes setores transformem as questões ambientais em uma agenda positiva em favor de uma produção mais eficiente, de maior qualidade e capaz de limitar a expansão das fronteiras agrícolas. Com os novos tempos, os pecuaristas devem encarar como oportunidades de negócios, a recuperação de áreas de proteção ambiental e os investimentos na diversificação de suas propriedades. O Brasil, que há décadas assumiu a condição de celeiro do mundo, tem um papel importante nesse novo cenário da agropecuária mundial, que será pautado pelo aumento da demanda por alimentos e pelas restrições ambientais à abertura de novas áreas agrícolas (SOUZA, 2011).

Neste cenário, a ovinocultura de corte está se tornando uma atividade cada vez mais atraente para a diversificação da produção agropecuária, pelos ovinos serem animais dóceis, de fácil lida e que não necessitam de áreas extensas para a criação, quando comparados com os bovinos, por apresentarem período de gestação mais curto em relação às vacas, pela idade de abate ser menor nos cordeiros em relação aos bois, permitindo que os rebanhos ovinos apresentem altas taxas de desfrute e uma elevada produção de carne por hectare-ano e por ovelha. Ainda há o fato de que a espécie ovina apresenta um rápido ciclo reprodutivo, pois as ovelhas têm vida útil de seis anos, sendo que as borregas e os machos atingem a puberdade entre o sexto e oitavo mês (VECHI, 2010). 
Por outro lado, os ovinos são suscetíveis a uma série de doenças, algumas delas características da própria espécie, que se não bem controladas através de um adequado manejo sanitário, afetam a eficiência reprodutiva do rebanho, prejudicam o desenvolvimento dos animais e provocam altos índices de mortalidade. As endoparasitoses, quando não bem controladas, causam perda de peso de 30 a $40 \%$ nos animais jovens, grande mortalidade de cordeiros, além do gasto com medicamentos, tornando a ovinocultura uma atividade economicamente inviável e impraticável pelos pequenos e médios produtores rurais (VECHI, 2010).

Para que a criação de ovinos dê bons resultados é preciso obter alta eficiência reprodutiva do rebanho e alto índice de desmama, o que implica em maior número de cordeiros nascidos e baixa taxa de mortalidade na fase de amamentação. Estes fatos, aliados a um bom desempenho corporal dos cordeiros e a custos de produção compatíveis com o mercado da carne, garantiriam a boa oferta de animais na idade ideal para o abate a preços competitivos (VECHI, 2010).

A ovinocultura e caprinocultura vivem momentos de grande transformação. Aos poucos, as tradicionais criações de subsistência cedem espaço e se inserem num amplo contexto de negócios, são capris no Nordeste trabalhando com fertilização in vitro, cabanhas no Rio Grande do Sul com rastreabilidade, frigoríficos especializados industrializando carne, distribuidoras exclusivas abrindo portas em São Paulo. Em 2010 e 2011, a demanda pelos 2 tipos de carne ultrapassou de longe a oferta, que ficou em aproximadamente 0,4 kg/per capita/ano (NASCIMENTO, 2012).

Ao observar o consumo brasileiro de carne de frango e de bovinos, que é de respectivamente 47 e 40 kg/per capita/ano, e ao compararmos o consumo de carne ovina em países como Austrália e Uruguai, que é de 14,53 e 6,23 kg/per capita/ano, conclui-se que o consumo de carne ovina é muito baixo, tem muita possibilidade de crescimento e especialistas no assunto afirmam que se o consumo brasileiro subir para $2,5 \mathrm{~kg} /$ per capita/ano, 
em uma década, o plantel teria que aumentar de 16 milhões de cabeças, que é o número atual, para 100 milhões (VIANA, 2008; NASCIMENTO, 2012).

O baixo consumo, no Brasil, se deve a vários fatores dentre eles, a produção e a comercialização ainda estarem desorganizadas, há falta de uma oferta em quantidade e de forma constante de cordeiros para o mercado, bem como a produção de carne de baixa qualidade, falta de propaganda que incentive os consumidores a integrarem esta carne em seus cardápios, entre outros. Mesmo com o baixo consumo, grande parte da carne ovina oferecida aos consumidores é uma carne importada (CANOVA; MOREIRA, 2009; HOLANDA JUNIOR; SÁ; ARAÚJO, 2010).

O rebanho ovino brasileiro é insuficiente para suprir o mercado interno, dependendo da importação que é essencial para atender a baixa demanda (RIGHI, 2005). De 1997 a 2008 a importação de carne ovina passou de US\$ 6 milhões para mais de US\$ 23 milhões, mas a participação das importações em 2009 teve baixa de 6,9\% em relação a 2008, porque a produção de carne ovina no Brasil em 2009 superou a dos anos anteriores (SOUZA, 2010).

O Brasil por participar do crescente mercado internacional de carne ovina, principalmente como importador, demonstra que existe um mercado interno ávido por consumir a carne destes pequenos ruminantes. Também demonstra que existem oportunidades reais para os produtores brasileiros desenvolverem a cadeia produtiva de ovinos e, assim, ocuparem de forma mais racional as imensas áreas de pasto disponíveis no país (SORIO, 2010).

Souza (2010) afirma que a importação da carne ovina traz alguns benefícios para o Brasil, pois contribuem para tornar a carne ovina mais visível e disponível para o consumidor final; aumentando com isso, o volume de consumidores potenciais; estimulam o hábito de consumo e sustentam uma relativa regularidade de oferta no varejo. A carne ovina importada, indiretamente, tende a atrair novos investidores, criadores, produtores e 
ORTUNHO, V.V. Revisão da literatura: mineralização e perfil metabólico em ovinos. PUBVET, Londrina, V. 7, N. 10, Ed. 233, Art. 1537, Maio, 2013.

indústrias para a atividade, permitindo a expansão horizontal e vertical da cadeia produtiva no Brasil.

Assim, a evolução da ovinocultura brasileira torna-se cada vez mais evidente, a superação anual dos números é notória, mantendo o setor aquecido, em constante crescimento e com uma tendência altamente positiva em longo prazo, permitindo a consolidação e o desenvolvimento da ovinocultura comercial em todo o país, aumentando o número de produtores desses animais e de investimento nessa cultura (SOUZA, 2010).

A literatura relata que o desenvolvimento e crescimento da ovinocultura trouxeram consigo um aumento na incidência de muitas doenças, em especial as de origem metabólica, como a Intoxicação Cúprica, Urolitíase e a Toxemia da Prenhez. Segundo Ortolani (2009), no decorrer das últimas décadas o número de atendimentos, dessa última patologia citada, no Hospital de Ruminantes da Faculdade de Medicina Veterinária e Zootecnia da Universidade de São Paulo tem aumentado continuamente, passando de 1,6\% na década de 80 , para $3,3 \%$ na de 90 e chegando a 4,0\% na primeira década deste século.

Esse aumento na incidência de doenças metabólicas deve-se a algumas razões entre elas citam-se: o aumento das exigências produtivas impostas pelo ser humano mediante a seleção genética e os sistemas de manejo intensivo, uma vez que facilmente podem-se produzir desequilíbrios entre $o$ ingresso de nutrientes no organismo, seu metabolismo e os egressos (CONTRERAS; WITTWER; BÖHMWALD, 2000).

À medida que foram incluídos o melhoramento genético e a seleção nos programas de criação de ovinos, estes animais passaram a apresentar maior ritmo de crescimento, maior ganho de peso, melhor conversão alimentar e maior rendimento de carcaça, consequentemente as suas necessidades nutricionais tornaram-se mais elevadas e se caso não forem atendidas aumenta-se a probabilidade do aparecimento das doenças metabólicas (MEDINA; NATEL, 2010). 
Essas patologias podem ocorrer de forma subclínica com diminuição de 10 a 30\% na produção e com alterações bioquímicas iniciais, as quais podem ser detectadas na urina, no leite e no sangue. Também podem aparecer na forma clínica resultando em abortos e até em morte de animais (GONZÁLEZ et al., 2000).

Os rebanhos ovinos podem ser afetados por desbalanços nutricionais e metabólicos em diferentes fases de desenvolvimento e produção (Contreras; Wittwer; Böhmwald, 2000). Porém, é no pré-parto que pode ocorrer o principal problema metabólico que acomete esta espécie, Toxemia da Prenhez.

A ocorrência dessa patologia pode ser evitada ou minimizada com a adoção de práticas simples, tanto no manejo nutricional, com a introdução de uma dieta adequada e balanceada, quanto no sanitário do rebanho com o controle de patologias que provoquem anorexia ou diminuição do apetite das fêmeas. Também, para prever a ocorrência da Toxemia da Prenhez têm-se sugerido a realização do perfil metabólico durante alguns períodos da gestação (ORTOLANI, 2009; SILVA; SILVA, 1983).

O emprego de técnicas corretas no manejo nutricional com a utilização de dietas balanceadas é importante para reduzir os custos com a alimentação, para que haja um ajuste na qualidade e quantidade da dieta fornecida, para que assim, sejam atendidas as necessidades específicas de cada categoria animal (MEDINA; NATEL, 2010).

Os novos avanços no campo e na nutrição animal introduziram no mercado, os complexos de minerais orgânicos, que têm despertado grande interesse nos pesquisadores e produtores, por possuírem algumas características de destaque como, absorção próxima a 100\%, alta estabilidade e alta biodisponibilidade (BARUSELLI, 2007).

O déficit de minerais no metabolismo também é um dos responsáveis pelas perdas na produção, pois se reflete negativamente no desempenho do rebanho, levando-o a uma baixa produção de leite e carne, 
ORTUNHO, V.V. Revisão da literatura: mineralização e perfil metabólico em ovinos. PUBVET, Londrina, V. 7, N. 10, Ed. 233, Art. 1537, Maio, 2013.

baixo índice de fertilidade, diminuição na taxa crescimento, má formação óssea e redução na resistência às doenças (SANSON; MOMBACH; SANTOS, 2010).

Para que as diversas atividades metabólicas do organismo possam ocorrer, os minerais precisam ser fornecidos adequadamente na dieta. As quantidades a serem ingeridas, variam, segundo as condições fisiológicas dos ruminantes: crescimento, lactação, gestação, engorda, produção de lã e mantença (SANSON; MOMBACH; SANTOS, 2010).

No contexto técnico-econômico, a alimentação é um ponto chave por ser um dos fatores que mais oneram a produção, porém pouco se sabe sobre a relação custo-benefício da inclusão dos minerais orgânicos na dieta e poucos são os estudos que avaliem os benefícios metabólicos oferecidos aos ovinos quando eles ingerem estes minerais. Sendo assim, urge a realização de pesquisas que avaliem os benefícios dos quelatos na ovinocultura (BOUCINHAS et al., 2006; GERASSEV; PEREZ; CARVALHO, 2006).

Como mencionado anteriormente, a análise do perfil metabólico permite através da realização de análises de sangue, diagnosticar o início de uma doença metabólica e tratá-la, evitando assim, a ocorrência de abortos, de mortes e diminuição da produção, podendo assim, ser utilizado para melhorar os índices produtivos na ovinocultura (WITTNER, 2000).

Apesar do grande avanço na ovinocultura brasileira que ocorreu nos últimos anos, resultados de variações sanguíneas de animais criados sob diferentes manejos, diferentes raças, idades, sexo, que estejam sob diferentes períodos produtivos e que estejam recebendo diferentes dietas, ainda são escassos e contraditórios (RICCÓ, 2004; BRITO et al., 2006). Dificultando assim, a prevenção de patologias metabólicas, tratamento e um maior entendimento sobre os animais criados no país, justificando pesquisas nessa área.

É indispensável à participação e o comprometimento de todos os agentes envolvidos na cadeia da ovinocultura como governo, pesquisadores, técnicos, produtores, associações, indústrias processadoras e comerciantes para o crescimento da atividade, para o estabelecimento de diretrizes, 
cumprimento de metas e articulação entre todos os elos da cadeia produtiva (HOLANDA JUNIOR; SÁ; ARAÚJO, 2010).

No Estado do Paraná, onde a ovinocultura não tinha tradição e se encontra atualmente em expansão, é fundamental a execução de uma série de estudos envolvendo as diversas raças disponíveis, de modo a permitir a evolução adequada e ordenada dessa atividade. É fundamental também que sejam realizados estudos que avaliem o perfil metabólico de animais saudáveis criados neste estado, durante os vários períodos reprodutivos e produtivos, para que sejam introduzidos novos valores de referência na hematologia e na bioquímica sanguínea (BARBOSA et al., 2001).

\section{REVISÃO DA LITERATURA}

\subsection{IMPORTÂNCIA DA NUTRIÇÃO}

O aumento no conhecimento da genética, das práticas de manejo e da nutrição têm sido fundamental para a melhoria dos índices na produtividade animal (LINDSAY, 2006).

A nutrição adequada é imprescindível para o ovinocultor que deseja atingir boa produtividade e rentabilidade na sua criação. O grande desafio dos ovinocultores é gerenciar a alimentação do rebanho de forma correta, para que este não seja um fator limitante na produção (VIANA, 2001).

Para se adotar um manejo alimentar racional e econômico o conhecimento sobre as exigências produtivas é fundamental, pois o manejo inadequado, Figura 1, principalmente nas fases de gestação e lactação, poderá levar a ocorrência de distúrbios metabólicos, abortos ou diminuição do peso ao nascer dos cordeiros, aumento na taxa de mortalidade, diminuição da produção de leite e por consequência, menores taxas de crescimento, gerando um menor retorno econômico ao produtor (PILAR; PEREZ; SANTOS, 2002; SANSON; MOMBACH; SANTOS, 2010; VIÑOLES et al., 2005). 


\section{MANEJO ALIMENTAR}

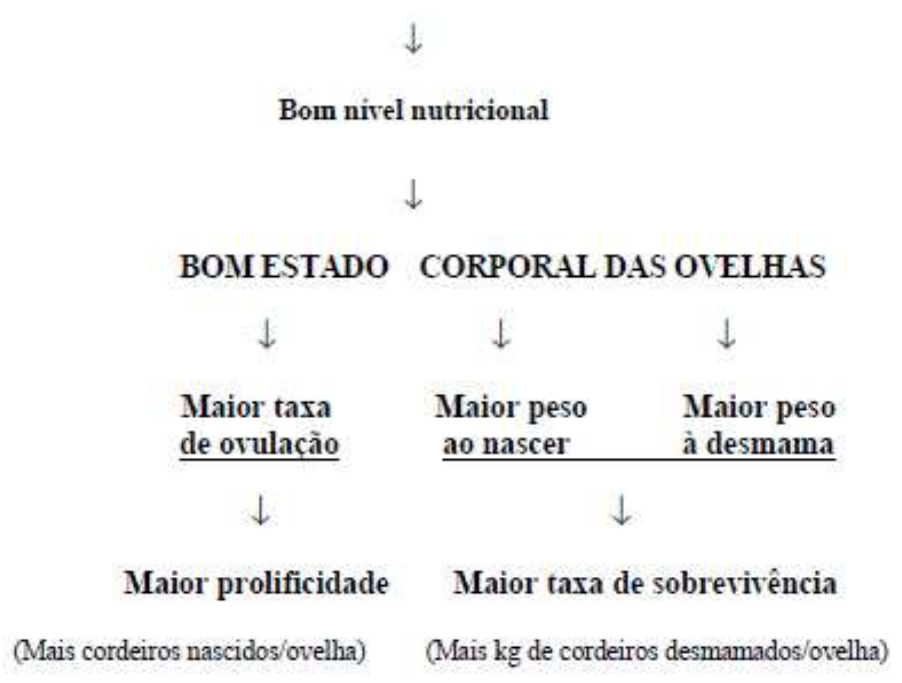

Figura 1 - Efeitos da nutrição sobre o segmento inicial da produção de carne ovina. Fonte: Pilar, Perez e Santos (2002).

A nutrição também influencia a puberdade nos ovinos, sabe-se que esse é um importante fenômeno reprodutivo e que adiantá-lo é um dos objetivos dos programas de seleção, pois se reduz o intervalo entre as gerações e acelera os progressos genéticos (BATHAEI; LEROY, 1997). A adequada alimentação na fase de recria permite que borregas sejam acasaladas mais cedo, ao atingirem $70 \%$ do peso adulto, com primeiro parto dos 12 aos 14 meses de idade (SUSIN,1996 apud HOMEM JUNIOR et al., 2007).

Macedo e Macedo (2008) observaram num trabalho de revisão que a nutrição inadequada da ovelha prenhe, apresentou alta correlação com mortalidade do cordeiro recém-nascido, pois influenciou de forma significativa o peso ao nascer e a maior ou menor susceptibilidade a doenças e adversidades climáticas.

O desmame precoce e a terminação de cordeiros em confinamento têm despertado o interesse de ovinocultores, pois constituem formas de aumentar a produção de cordeiros para o abate. O peso do cordeiro ao nascimento e à desmama está intimamente relacionado à taxa de 
sobrevivência e ao histórico nutricional da ovelha durante os períodos de gestação e lactação (ROSA et al., 2007).

Salem et al. (2009) pesquisaram 171 cordeiros da raça Barbarine que receberam diferentes dietas, por um período de 200 dias. Os autores concluíram que os animais que tiveram uma diminuição do peso vivo no período estudado demoraram mais tempo para apresentarem o primeiro cio, quando se comparou com os animais que receberam uma dieta adequada.

O primeiro passo num programa nutricional é o conhecimento das exigências dos animais, pois os requerimentos em energia, proteína e minerais são afetados por diversos fatores como idade, tamanho corporal, estado fisiológico, nível de produção e fatores do meio ambiente como temperatura, umidade e intensidade solar. Ao se tratar das necessidades nutricionais, atenção especial deverá ser dada na época de cobertura, gestação e durante a lactação (GRACE, 1984).

\subsection{SUPLEMENTAÇÃO MINERAL}

A introdução de raças caprinas e ovinas especializadas para a produção de carne e leite, bem como a crescente demanda por produtos e subprodutos da caprinocultura e da ovinocultura aumentaram a pressão por sistemas de produção mais eficientes para criação desses animais, em virtude da maior exigência nutricional e da necessidade de abastecimento dos mercados consumidores (BARROS et al., 2006).

Para que as diversas atividades metabólicas do organismo possam ocorrer, os minerais precisam ser fornecidos adequadamente na dieta. As quantidades a serem ingeridas, podem variar segundo as condições fisiológicas dos ruminantes: crescimento, produção (feto, carne, leite, lã) e mantença (SANSON; MOMBACH; SANTOS, 2010).

A suplementação mineral é utilizada na tentativa de suprir as deficiências nutricionais da pastagem, para proporcionar o balanceamento da dieta e possibilitar que os animais desenvolvam seu potencial genético, 
mantendo-se saudáveis, devendo ser realizada em todas as fases do ciclo produtivo, o ano inteiro e em todas as regiões do país (BARROS et al., 2006; FARINATTI et al., 2006).

As forragens geralmente não fornecem os minerais na quantidade ideal para que as necessidades dos animais possam ser atingidas por isso, rebanhos que não são suplementados adequadamente com as misturas minerais poderão desenvolver doenças carenciais com prejuízo no crescimento, mantença e nas fases reprodutivas (KHAN et al., 2010; SUTTLE, 2010).

As deficiências minerais são muito comuns, principalmente quando os animais são criados em condições de pastejo, o que limita a produção (KHAN et al., 2010). A maioria das deficiências ou desbalanços não se manifestam clinicamente, mas podem causar perdas em índices produtivos, mesmo em níveis subclínicos, Figura 2.

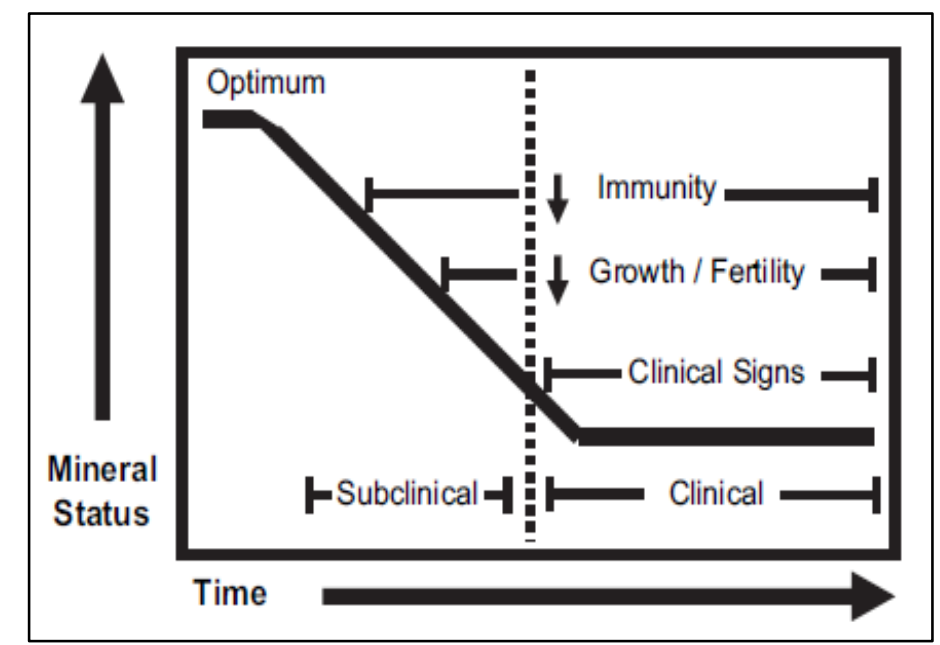

Figura 2 - Os efeitos da deficiência dos minerais-traço na saúde e desempenho dos animais. Fonte: Olson, 2007

O diagnóstico clínico de uma deficiência mineral é complexo, já que, em grande parte das vezes, os sinais são comuns a outros transtornos (RICCÓ, 2004). A deficiência mineral reflete-se negativamente no desempenho do rebanho, levando-o a uma diminuição da produção de leite e carne, do 
índice de fertilidade, imunidade, da taxa de crescimento, do rendimento de carcaça, do desempenho reprodutivo e produtivo, assim como diminuição no crescimento e má formação óssea (ANTUNOVIĆ et al., 2002; SANSON; MOMBACH; SANTOS, 2010).

A importância e a função dos minerais são bem conhecidas, mas alguns deles são utilizados principalmente para funções estruturais, sendo constituintes de órgãos e tecidos, como o cálcio; fósforo e enxofre. Ou ainda, podem ajudar na manutenção do balanço ácido-base como, o sódio, potássio e o cloro. Podem atuar principalmente como cofatores enzimáticos, como o magnésio e o cobre. Fazem parte de enzimas como o zinco, molibdênio, selênio. $O$ iodo e o cobalto fazem parte de hormônios e de vitaminas, respectivamente. Resumindo, os minerais são, então, fundamentais para a mantença, reprodução, produção dos animais mantendo assim, a saúde dos mesmos (PEDREIRA; BERCHIELLI, 2006; SUTTLE, 2010).

Os minerais também são necessários para proporcionar algumas das características qualitativas da carne, baseado nisso Osorio et al. (2007), avaliaram carcaças de cordeiros que haviam sido alimentados com leite e outras carcaças de cordeiros que tinham recebido substituto de leite. Os autores encontraram no músculo dos animais que receberam substituto de leite maiores concentrações de manganês, enquanto o outro grupo teve maior concentração de zinco e sódio. O fígado destes animais apresentou maiores concentrações de potássio, fósforo e cobre, enquanto que o fígado dos alimentados com leite teve maiores concentrações de zinco e manganês. Os autores concluíram que a composição mineral da carcaça dos cordeiros é alterada pela alimentação que os animais recebem, podendo esta, então, alterar e comprometer a qualidade da carne.

Giadinis et al. (2011) acompanharam 13 rebanhos com alta incidência de mastite clínica e 5 que tinham baixa incidência e observaram que houve diferença estatística entre os 2 rebanhos na concentração de selênio e vitamina A plasmática, mas não havia diferença na concentração de vitamina E. Os autores constataram também que, animais que possuíam mastite 
relacionada com S. aureus ou M. agalactiae tinham menores concentrações de Se, vitamina A e vitamina E quando se comparava com o sangue dos animais saudáveis. Os autores concluíram que erros nutricionais afetam a imunidade dos animais, deixando-os predispostos a patologias.

Sabe-se que durante a lactação e gestação a demanda de alguns minerais aumenta, como o cálcio e o fósforo, então, especial atenção deve ser dada nessas fases para que as necessidades sejam atendidas, evitando-se a ocorrência de doenças (ABDELRAHMAN, 2002). Percebe-se o quão importante é que uma mistura mineral seja formulada para cada espécie e para cada fase reprodutiva e produtiva do animal.

A escolha dos componentes que constituem uma mistura mineral pode ser determinada por alguns fatores entre eles, a pureza e o custo do mineral requerido; a forma química do elemento, que pode determinar a estabilidade e disponibilidade do mesmo; tamanho da partícula, que pode afetar a facilidade de absorção do mineral; compatibilidade com outros ingredientes da dieta e também o risco de toxicidade, que pode afetar a saúde do animal e do consumidor de carne ou de leite (SUTTLE, 2010).

Mesmo havendo uma grande variedade de misturas minerais no mercado, há alguns produtores que oferecem aos ovinos a mesma suplementação mineral oferecida aos bovinos, o que pode causar patologias, pois as ovelhas são mais sensíveis e podem desenvolver uma toxicidade ao cobre e a outros minerais (ECKERT et al., 1999).

Por ainda haver a necessidade de conscientizar os produtores sobre os benefícios da suplementação mineral correta, esta pesquisa é importante também para contribuir que isso aconteça e como consequência favorecer o crescimento da ovinocultura. 
ORTUNHO, V.V. Revisão da literatura: mineralização e perfil metabólico em ovinos. PUBVET, Londrina, V. 7, N. 10, Ed. 233, Art. 1537, Maio, 2013.

\subsubsection{Experimentos realizados com minerais inorgânicos}

Alguns experimentos com minerais inorgânicos foram desenvolvidos nos últimos anos na espécie ovina e neste item, alguns deles serão detalhados.

Guinan et al. (2005) com o objetivo de avaliarem o efeito da alimentação mineral na absorção de imunoglobulina $G$ pela progênie, utilizaram 52 ovelhas prenhes de um feto divididas em 4 grupos. Um grupo não recebeu mistura mineral, enquanto os outros receberam na semana 6 , 4, 2 préparto. A dose fornecida era de $48 \mathrm{~g} /$ animal e a mistura continha Cálcio, Fósforo, Sódio, Manganês, Magnésio, Zinco, Selênio, Cobalto, Iodo e vitamina E. As fêmeas foram ordenhadas com 1, 10 e 18 horas pósparto para ser avaliada a concentração de IgG. Os autores concluíram que a suplementação das ovelhas e o nível de minerais utilizados nas duas semanas finais da gestação resultaram numa menor habilidade de absorção de IgG colostral.

Boland et al. (2005) com o objetivo de avaliarem a influência de uma mistura mineral inorgânica contendo Zinco, Fósforo, Selênio, Iodo, Magnésio, Manganês e Cobalto, durante as últimas 6 semanas de gestação na produção e na qualidade do colostro, os autores dividiram 108 ovelhas em 9 tratamentos que receberam a mistura com vários níveis de inclusão desses minerais. O peso dos cordeiros ao nascer não sofreu influência dos tratamentos e os cordeiros nascidos das fêmeas do grupo controle, que não receberam suplemento, e do grupo que não recebeu iodo tiveram maiores eficiências de absorção de IgG que os outros tratamentos. Os autores concluíram que altos níveis de inclusão na dieta de iodo causaram uma menor taxa de absorção de IgG.

Hall et al. (2009) utilizaram ovelhas de 3-5 anos, 15 receberam somente um pasto super-fertilizado com selênio, outras 15 receberam o mesmo pasto, porém sem fertilização e tiveram livre acesso a uma mistura comercial mineral que continha minerais inorgânicos como Selênio, Cálcio, Fósforo, Sódio, Cloro, Magnésio, Cobalto, Manganês, Iodo, Ferro, Zinco, 
Vitaminas A, D e E. Após 40 dias, os animais foram colocados num pasto sem fertilização pelo mesmo período e não receberam suplementação mineral. Durante o período experimental, os animais tiveram o sangue colhido para mensuração da concentração de selênio. Os autores encontraram que as ovelhas que receberam a forragem fertilizada apresentaram durante todo o experimento, maiores concentrações de selênio que as ovelhas do outro grupo, mostrando que os autores forneceram quantidades do mineral suficientes para manter os níveis de selênio sanguíneos normais. Nenhum animal mostrou sinais clínicos de deficiência deste elemento.

\section{- Cálcio e Fósforo}

Rajaratne et al. (1990) realizaram 2 experimentos, sendo que no primeiro, eles utilizaram 6 fêmeas lactantes divididas em 2 grupos; um deles recebeu dieta com alto teor de proteína, enquanto o outro recebeu baixo teor de proteína. No segundo experimento, os autores utilizaram 4 ovelhas no final da gestação, divididas em 2 tratamentos, 2 ovelhas receberam 2,88 e 2,19 $\mathrm{g} / \mathrm{Kg} / \mathrm{dia}$ de cálcio e fósforo respectivamente, enquanto as outras receberam 10,23 e 7,56 $\mathrm{g} / \mathrm{Kg} / \mathrm{dia}$ de cálcio e fósforo. As fêmeas receberam os suplementos a partir dos 50 dias de gestação. Após o parto, elas receberam uma dieta formulada para atender as exigências de lactação. Em ambos os experimentos, não houve diferença estatística entre os grupos, quando foi medido o nível destes minerais no plasma. Os autores concluíram que a reabsorção de cálcio e fósforo do esqueleto por fazer parte da fisiologia durante a lactação e gestação é uma resposta que independe do balanço de nitrogênio.

Abdelrahman et al. (2002) estudaram o efeito da suplementação com carbonato de cálcio e de vitamina A em 40 ovelhas Awassi de 3,5 anos, durante a gestação e lactação. Elas foram divididas em 4 tratamentos que receberam diferentes níveis de inclusão: grupo 1 recebeu $1,4 \%$ de cálcio na dieta; grupo 2 recebeu 2,4\% de cálcio; grupo 3 recebeu 1,4\% de cálcio na ração mais 2 doses intramusculares de vitamina A e grupo 4 recebeu 2,4\% 
cálcio na ração mais 2 doses intramusculares de vitamina A. Amostras de sangue das mães, dos cordeiros e de leite foram colhidas a cada 20 dias e os animais foram pesados a cada 15 dias. A concentração de cálcio no soro das ovelhas e dos cordeiros foram maiores nos pertencentes ao grupo 4. Um significativo aumento no ganho de peso dos cordeiros foi apresentado nos animais do grupo 2 e 4, apesar de não ter sido encontrado diferença no ganho de peso das fêmeas durante o experimento. Os autores concluíram que 2,4\% de cálcio com ou sem vitamina A para ovelhas Awassi melhoraram a concentração de cálcio no plasma e o ganho de peso dos cordeiros.

Sabe-se que o requerimento de cálcio aumenta rapidamente no final da gestação e que a deficiência deste mineral resulta em baixo crescimento e desenvolvimento do feto. Baseado nisso Abdelrahman, (2008) estudou os efeitos da suplementação com carbonato de cálcio e vitamina $A$ em 40 ovelhas prenhes da raça Awassi. As fêmeas foram divididas em 4 tratamentos e receberam respectivamente $1,4 \%$ de cálcio (controle); $2,4 \%$ de cálcio; $1,4 \%$ de cálcio mais vitamina $A ; 2,4 \%$ de cálcio mais vitamina $A$. As amostras de sangue foram colhidas com 45 dias antes do parto, no dia do parto, 30 e 60 dias após o parto e dos cordeiros, as colheitas foram realizadas nos dias 0,30 e 60. O autor encontrou nas fêmeas do grupo 4 maiores concentrações de cálcio no dia do parto e com 60 dias após. O colostro das fêmeas dos grupos 2 e 4 apresentaram maiores concentrações de cálcio. Os cordeiros dos grupos 1 e 2 apresentaram maiores ganhos de peso. $O$ autor concluiu novamente neste experimento, que o aumento da concentração de cálcio na alimentação de ovelhas da raça Awassi no final da gestação, com ou sem adição de vitamina $A$, melhora a concentração de cálcio no colostro e no soro sem apresentar prejuízo na saúde e no desempenho dos cordeiros.

- Cloro $(\mathrm{Cl})$ e Sódio $(\mathrm{Na})$

Chadwick et al. (2009) acompanharam ovelhas da raça Merino do $60^{\circ}$ dia de gestação até o $21^{\circ}$ dia de lactação, que receberam pelets contendo $14 \%$ de $\mathrm{NaCl}$ e o grupo controle $2 \%$ de $\mathrm{NaCl}$. Os autores 
observaram que as fêmeas que ingeriram alta quantidade de sal, ingeriram menos alimento, beberam menos água, tiveram a atividade da enzima renina alterada, quando comparadas com as ovelhas do grupo controle, porém o ganho de peso foi semelhante entre os dois grupos.

\section{- Cobalto}

Wang et al. (2007) suplementaram cordeiros Chinese Poll Dorset $\times$ Small Tailed Han de 12 semanas com diferentes níveis de inclusão de cobalto inorgânico. Os animais foram divididos nos seguintes tratamentos: um grupo recebeu $0,086 \mathrm{mg} \mathrm{Co} / \mathrm{kg} / \mathrm{PV}$ e os outros respectivamente 0,$25 ; 0,50$; 0,75 e $1 \mathrm{mg} \mathrm{Co} / \mathrm{kg}$ por 10 semanas. O tratamento que recebeu 0,5 mg $\mathrm{Co} / \mathrm{kg} / \mathrm{PV}$ apresentou maior ganho de peso e maior concentração de vitamina $B_{12}$ no sangue. A glicemia apresentou-se linearmente maior, conforme se aumentava a concentração de cobalto ingerida. Os autores concluíram que a adição desse mineral foi benéfica para a formação de glicose pela gliconeogênese e recomendaram uma adição deste mineral entre 0,30 e 0,50 $\mathrm{mg}$.

Boland et al. (2008) ofereceram suplementação mineral com cobalto nas últimas três semanas de gestação e avaliaram a concentração de IgG e de vitamina E no soro dos cordeiros com 24 e $72 \mathrm{~h}$ pós-parto. Utilizaramse 60 ovelhas de aproximadamente 4 anos de idade, divididas em 2 grupos. Um dos grupos não recebeu o mineral e o outro recebeu $0,20 \mathrm{mg}$ cabeça/dia. Os autores concluíram que a ingestão de altos níveis de cobalto durante as 3 últimas semanas de gestação, diminuiu a concentração de vitamina E no soro dos cordeiros, mas não foi encontrada diferença significativa na concentração de IgG entre os grupos avaliados.

- Cobre

White et al. (1989) testaram a hipótese de que a adição de cobre associado ou não com molibdênio na dieta, reduz a quantidade de selênio no plasma das ovelhas. Para isso, os autores utilizaram 36 ovelhas adultas da 
raça Hampshire, as quais foram divididas em 4 grupos: ração base, ração base $+10 \mathrm{mg} / \mathrm{kg} \mathrm{Cu}$, ração base $+10 \mathrm{mg} / \mathrm{kg}$ Mo e ração base $+10 \mathrm{mg} / \mathrm{kg} \mathrm{Cu}+10$ $\mathrm{mg} / \mathrm{kg}$ Mo. O molibdênio foi oferecido na forma de molibdato de sódio e o cobre na forma de carbonato cúprico. O experimento iniciou um mês antes da estação de monta. Colheu-se sangue das fêmeas com 9 e 17 semanas de gestação; 3 dias após o parto e na desmama. O sangue dos cordeiros foi colhido com 2, 4, 6, 8 e 10 semanas após o nascimento, depois deste período eles foram eutanasiados e tiveram analisados, o fígado e rins. O nível de selênio no plasma em todos os grupos diminuiu durante a gestação e lactação.

Cheng et al. (2010) relataram que pesquisas demonstram que a suplementação com cobre pode afetar o metabolismo dos lipídeos, que aumentam in-vitro o volume das células adiposas e a taxa de lipólise, por isso esses autores dividiram 50 cordeiros Dorper×Mongolia de 3 meses de idade em 4 tratamentos: controle (sem suplementação com Cobre); $10 \mathrm{mg} \mathrm{Cu} / \mathrm{Kg} / \mathrm{PV}$ de cobre- lisina; $20 \mathrm{mg} \mathrm{Cu} / \mathrm{Kg} / \mathrm{PV}$ de culisina e $10 \mathrm{mg} \mathrm{Cu} / \mathrm{Kg} / \mathrm{PV}$ de cloreto de cobre tribásico, para avaliarem possíveis alterações na função de hormônios e de enzimas lipogênicas e lipolíticas. Amostras de sangue foram colhidas nos dias 0,30 e 60 . Houve uma diminuição da quantidade de insulina plasmática nos dias 30 e 60 nos animais suplementados. Os autores concluíram que a suplementação com cobre alterou o metabolismo da insulina, diminuiu a atividade das enzimas lipogênicas e aumentou a atividade das enzimas lipolíticas no tecido subcutâneo, adiposo e hepático de cordeiros.

\section{- Enxofre}

Plessis, Van Niekerk e Coetzer (1999) suplementaram ovelhas Merino com molibdênio e enxofre em doses diferentes para induzirem a deficiência de cobre e verificaram que não houve diferença entre os grupos na concentração de progesterona, embora $75 \%$ das fêmeas mais velhas tenham apresentado cio silencioso. Os autores concluíram que a expressão ou produção dos hormônios $\mathrm{LH}, \mathrm{FSH}$ e estrógeno sofrem prejuízo quando o enxofre e o molibdênio são oferecidos em altas doses. 


\section{- Iodo}

Potter et al. (1984) utilizaram 30 ovelhas da raça Merino de 3 anos de idade, sendo que 10 delas pertencentes ao grupo controle recebiam iodo na quantidade adequada, via suplementação mineral; 10 receberam uma injeção muscular contendo iodo no $100^{\circ}$ dia de gestação, e outras 10 fêmeas eram mantidas com severa deficiência deste mineral. Todos os animais foram acompanhados no período seco e até os 140 dias de gestação, sendo que foi feita cesariana. A administração de iodo produziu uma notável melhora na função tireiodiana e na aparência dos fetos, como formação de lã e estrutura óssea.

\section{- Flúor}

Kessabi et al. (1985) utilizaram 16 ovelhas da raça Sardy que receberam diferentes doses de flúor via oral no final do experimento, dia 7, os animais foram mortos e os autores observaram que os animais que receberam a maior dose do mineral, $2 \mathrm{mmol}^{-} / \mathrm{kg}$ tiveram anorexia, congestão na conjuntiva, duodeno, fígado, rins e pulmão, maiores quantidades do mineral no plasma foram encontradas e os autores concluíram que intoxicação provocada por este mineral provoca falha renal e hepática.

- Magnésio

Matsunobu et al. (1990) dividiram 10 ovelhas em 2 grupos um deles recebeu uma dieta adequada enquanto o outro recebeu baixa quantidade de magnésio e alta de potássio. Os resultados encontrados sugeriram que a secreção de insulina e entrada de glicose nos tecidos é menor nos animais com hipomagnesemia.

Achmadi, Sano e Terashima (2001) suplementaram 18 ovelhas Suffolk que estavam divididas em 2 grupos, sendo que um deles recebeu menos magnésio, mais potássio que o recomendado e os animais foram ainda submetidos ao estresse, enquanto o outro grupo recebeu dieta adequada e não foi submetido ao estresse. Em todos os animais foi realizado o teste de infusão 
de glicose e os autores concluíram que o tratamento teve menos magnésio no plasma, que a hipomagnesemia diminuiu a quantidade de glicose disponível e que houve uma diminuição da resposta a insulina nos tecidos.

- Manganês

Murillo, Plaza e Arruebo (1997) colheram segmentos de duodeno de ovelhas e foram rapidamente transferidas para o laboratório com o objetivo de estudarem os efeitos do $\mathrm{Mn}^{2+}, \mathrm{Zn}^{2+}, \mathrm{Ba}^{2+}$ e $\mathrm{Ca}^{2+}$ na contratilidade intestinal. Os autores concluíram que o manganês inibiu a frequência e amplitude das contrações enquanto que os outros minerais aumentaram a atividade intestinal.

\section{- Selênio}

Por saberem dos benefícios da suplementação com selênio e por crerem que os níveis máximos desse mineral tolerados na dieta estejam subestimados, Davis et al. (2006), realizaram um experimento cujo objetivo foi determinar o nível máximo tolerável de selênio durante a gestação e lactação, utilizando, usaram 41 ovelhas Rambouillett de 4 anos de idade, que estavam com 57 dias de gestação. As fêmeas foram separadas em 6 grupos que receberam quantidades diferentes de selenito de sódio. $O$ experimento teve duração de 72 semanas. Foram analisados o sangue dos animais, a lã, ganho de peso e também foi realizado necropsia para que fossem analisados os músculos e órgãos. Os autores não encontraram diferença no ganho de peso dos animais e não houve interação do tratamento com o tempo. Os níveis de selênio no plasma, na lã e nos órgãos foram maiores conforme as doses ingeridas aumentaram, porém em nenhum momento os animais apresentaram sinais clínicos de toxicose. Os valores encontrados de albumina, FA, ALT, AST e CK estavam dentro da normalidade para a espécie, mas GGT apresentou-se com valores elevados. Os autores relataram que não houve evidências nem hematológicas nem histopatológicas de que as ovelhas do experimento tivessem tido toxicose. Os autores concluíram que mais pesquisas devem ser 
ORTUNHO, V.V. Revisão da literatura: mineralização e perfil metabólico em ovinos. PUBVET, Londrina, V. 7, N. 10, Ed. 233, Art. 1537, Maio, 2013.

realizadas para que se possa estimar melhor qual é o nível tolerado deste mineral.

Kojouri e Shirazi (2007) pesquisaram 14 ovelhas da raça LoriBakhtiari no final da gestação e forneceram selênio inorgânico e vitamina $E$ injetável para um grupo enquanto que, para o grupo controle forneceram água destilada pela mesma via, com o objetivo de avaliar se o tratamento afeta a concentração de $\mathrm{Cu}, \mathrm{Zn}$, Fe, Mo e Co no soro. No parto, a concentração de $\mathrm{Fe}$ foi maior nos cordeiros cujas mães eram do grupo controle, enquanto os outros minerais apresentaram concentrações semelhantes entre os grupos. Os cordeiros também foram avaliados quando estavam com 1 mês de idade e os nascidos das ovelhas do grupo experimental tiveram maiores concentrações de ferro e cobre no plasma, porém houve uma redução na concentração de zinco. Os autores concluíram que o aumento da concentração de cobre e ferro durante as primeiras semanas de idade pode resultar em deficiências de zinco.

Khan et al. (2010) realizaram um experimento com 30 ovelhas da raça Kajli de 3 anos de idade e de aproximadamente $36 \mathrm{~kg}$, separadas em fêmeas lactantes, secas e machos. O objetivo foi avaliar as alterações do selênio no plasma dos animais durante o verão e o inverno. Os autores avaliaram a quantidade de selênio nos pastos e no plasma dos animais e observaram que a concentração de selênio foi maior no verão, principalmente nos machos, enquanto que nas lactantes, houve uma alta incidência de deficiência deste mineral, por isso, os autores concluíram que a adição de selênio na mistura mineral é necessária para evitar prejuízos ao rebanho.

Mohri et al. (2011) pesquisaram 16 cordeiros da raça Baloochi com 70 dias de idade que foram divididos em 2 grupos, sendo que um deles recebeu vitamina $E$ e selenito de sódio injetados na dose de $0,2 \mathrm{mg} / \mathrm{kg}$ e o outro grupo recebeu a mesma dose de solução salina, os autores não encontraram diferença no ganho de peso entre os grupos, na glicemia, na hemoglobina, no leucograma, na albumina plasmática e na proteína total, enquanto o grupo tratado com o mineral teve uma diminuição na enzima AST e no número de eosinófilos. Os autores concluíram que a administração deste 
mineral não mostrou efeitos benéficos neste estudo e nos outros que têm sido realizados, isto se deve a dose utilizada, tempo de tratamento, tipo de mineral utilizado, incidência de doenças carenciais relacionadas com este mineral na região em estudo.

- Zinco

Henry, Littell e Ammerman (1997) relataram que há poucos trabalhos informando sobre o efeito da ingestão de diferentes doses de zinco nos ruminantes. Baseados nisso os autores realizaram dois trabalhos. No primeiro, foram utilizados 24 cordeiros de 44,7 $\pm 4,0 \mathrm{~kg}$, alimentados com 41 $\mathrm{mg} / \mathrm{kg} \mathrm{Zn}$ na matéria seca, separados em diferentes grupos que receberam doses de $0 ; 500 ; 1000 ; 1500 ; 2000$ ou $2500 \mathrm{mg} / \mathrm{kg} \mathrm{Zn}$ por 10 dias e os autores não encontraram diferença estatística na ingestão de alimento entre os grupos. No segundo experimento 27 cordeiros, com $64,1 \pm 7,5 \mathrm{~kg}$, foram suplementados com $0 ; 700 ; 1400$ ou $2100 \mathrm{mg} / \mathrm{kg}$ de $\mathrm{Zn}$ adicionados numa dieta base, ao final do experimento os animais foram eutanaziados e tiveram os órgãos e sangue analisados. Nesse experimento, os autores não encontraram diferença na concentração do mineral estudado no coração, nos músculos e ossos; porém no fígado e nos rins, a concentração de zinco aumentou conforme a dose ingerida aumentava. Os autores concluíram que o fígado e os rins são mais sensíveis ao zinco e que mais pesquisas que estudem esse mineral e que estudem a sua biodisponibilidade nas dietas devem ser feitas.

\subsubsection{Suplementação mineral orgânica}

No final da década de 80 , houve a introdução dos minerais orgânicos nas misturas ofertadas para os animais (PEIXOTO et al., 2005). Por isso, que seu uso na dieta de ruminantes tem despertado interesse nos pesquisadores, na indústria e nos produtores. 
Por ser uma tecnologia nova, há os defensores da sua utilização como, Spears (1996), que afirma que há relatos na literatura que o uso dos minerais quelatados melhora o ganho de peso, melhora as taxas reprodutivas e produtivas, a imunidade e a saúde dos animais.

Como também há aqueles, como Suttle (2010) e Peixoto et al (2005), que garantem que seu uso foi encorajado particularmente pela agressiva propaganda das empresas e questionam se seu uso é economicamente viável, relatando que seus benefícios econômicos e nutricionais devem ser consistentemente obtidos nas pesquisas.

Porém, é unânime entre os pesquisadores que novas pesquisas com essa suplementação devem ser realizadas, visando: definir o nível de inclusão nas dietas; estudar o custo-benefício da adoção dessa tecnologia, determinar o modo de ação dos quelatos nos ruminantes e estabelecer o comportamento desses minerais em relação às diferentes espécies de animais (SPEARS, 2003).

Os minerais orgânicos são formados por um mineral ligado a uma molécula orgânica, como aminoácidos ou carboidratos, e quando processados recebem o nome de quelatos e formam estruturas com características próprias (KELLOGG; KEGLEY, 2002; SPEARS, 2003; PAL et al., 2010). Atualmente a metionina tem sido utilizada como quelante, por ser absorvida rapidamente e em todos os sítios de absorção no intestino delgado (MORAES, 2000).

Algumas dessas características citadas anteriormente merecem destaque, como seu tamanho pequeno e a ausência de cargas elétricas, permitindo que os minerais sejam absorvidos sem sofrerem qualquer digestão (SPEARS, 2003).

Ao se comparar os minerais inorgânicos com os quelatos observa-se que, os primeiros podem formar complexos insolúveis quando se ligam com o fitato e com a gordura no intestino, podem também ter a concentração alterada devido à competição entre os elementos; como o caso do ferro e do manganês. Porém, os quelatos por estarem ligados aos 
aminoácidos são menos vulneráveis às interações que podem existir entre os minerais e entre os ingredientes da dieta, sendo então mais estáveis (SUTTLE, 2010).

Há também uma diferença na absorção dos minerais inorgânicos com os orgânicos, os primeiros, para serem absorvidos, no intestino delgado, devem se dissociar liberando íons metálicos (cátions), durante o trânsito no trato gastrintestinal e, caso isso não ocorra eles não serão absorvidos. 0 simples fato de se dissociarem não garante a absorção, pois o processo de passagem pela membrana celular, no intestino delgado, é dependente de proteínas transportadoras (MELLO, 2002 apud MONTEMÓR, 2005; SUTTLE, 2010).

O conjunto proteína transportadora e íon metálico deverá apresentar carga total neutra, caso contrário, não ocorrerá absorção. Não se pode esquecer que há a competição entre os diversos microminerais com as proteínas transportadoras, sendo que o excesso de certos elementos minerais poderá reduzir a biodisponibilidade de um ou mais elementos (MELLO, 2002 apud MONTEMÓR, 2005).

Já com os minerais orgânicos estas dificuldades na absorção não ocorrem, pois, como já mencionado anteriormente, eles são fixos num ligante orgânico, possuem carga neutra, apresentado assim, absorção direta pela membrana intestinal, não havendo então, a necessidade teoricamente, de proteínas transportadoras (BARUSELLI, 2000).

Outra característica importante que facilita a absorção dos complexos orgânicos é a solubilidade em pH fisiológico. De modo geral, eles apresentam solubilidade próxima a $100 \%$ em pH 2,0; então espera-se que, ao entrarem no intestino delgado, eles estejam altamente solubilizados (HOLWERDA; ALBIN; MADSEN, 1995).

Observa-se que é possível que a absorção do mineral no trato intestinal, e que sua separação com o aminoácido quelante, aconteçam no local onde o elemento mineral metálico será utilizado, sem que eles precisem 
entrar na cadeia metabólica, como acontece com todos os íons inorgânicos (DATTA; MONDAL; BISWAS, 2007).

Por todas essas características, alguns autores citam que os complexos de minerais orgânicos são mais biodisponíveis, sendo também estruturas moleculares menos tóxicas que os minerais inorgânicos, tendo como vantagem uma suplementação com elevada margem de segurança, tanto para o animal como para o consumidor de carne e leite (BARUSELLI, 2007; PECHOVA et al., 2009).

O elenco de produtos disponíveis no mercado não se restringe aos quelatos, recentemente apareceram outros complexos, como os transquelatos e os carboaminofosfoquelatos. O que diferencia um composto do outro, além da complexidade do processo industrial, é o tamanho da molécula e a estrutura na qual o mineral está ligado. Esses compostos continuam tendo como características: a baixa toxicidade e alta biodisponibilidade, agindo como potentes ativadores dos microrganismos ruminais e para todas as células do organismo do ruminante (BARUSELLI, 2007).

Algumas pesquisas estão sendo feitas nas mais diversas espécies animais para que haja a compreensão do efeito desses minerais no organismo, porém, na ovinocultura os resultados ainda são insuficientes. Alguns dos trabalhos realizados recentemente estão apresentados a seguir.

\subsubsection{Experimentos com minerais orgânicos}

\section{- Cromo Orgânico}

Kitchalong et al. (1995) pesquisaram 24 cordeiros Suffolk com média de $38 \mathrm{~kg}$ separados em dois grupos, um deles recebeu dieta controle e o outro grupo recebeu a mesma dieta, acrescida de $250 \mathrm{ppb}$ de tripicolinato de cromo, que continha $12 \%$ do mineral. O objetivo do trabalho foi investigar a influência do cromo orgânico na carcaça, no ganho de peso e nos parâmetros sanguíneos de cordeiros em crescimento. Nos dias 14, 49 e 77 após o início do experimento foram colhidas amostras de sangue dos animais em jejum e após 
3 horas da alimentação. Foram analisados os seguintes parâmetros: glicose, albumina, proteína total, colesterol total e uréia. Para avaliarem as características de carcaça, 3 animais do grupo experimental e 4 do controle foram eutanaziados. Os autores encontraram que o ganho de peso médio diário, ingestão de matéria seca, peso da carcaça, dos rins e do coração não foram afetados pelo tratamento. Os animais que receberam cromo tiveram $18 \%$ menos deposição de gordura na carcaça que os outros animais. A albumina apresentou efeito quadrático; proteína total, glicose e uréia não foram afetados pelo tratamento. Os autores concluíram, nesse trabalho, que o cromo orgânico exerce um efeito sutil no metabolismo de lipídios e dos carboidratos em cordeiros e que podem diminuir a deposição de gordura na carne desses animais, alterando a qualidade da carcaça de cordeiros. Consequentemente, sugeriram que a suplementação com cromo quelatado pode beneficiar a produção dos animais de rebanho pelo aumento da produção de carne e diminuição da deposição de gordura, sendo um benefício tanto para o produtor quanto para o consumidor. Acrescentaram, porém, que mais pesquisas que investiguem a relação do cromo nas características de carcaça e nos metabólitos sanguíneos são necessárias para que sejam elucidados os mecanismos de ação do mineral nas espécies de rebanho e sua viabilidade.

Forbes et al. (1998) estudaram os efeitos da suplementação com tripicolinato de cromo, nas respostas metabólicas e no ganho de peso de 8 ovinos Suffolk com peso de 58,9 $\pm 1 \mathrm{~kg}$, e 8 Gulf Coast Native com peso de $44,9 \pm 1 \mathrm{~kg}$. Os grupos controle de cada raça não receberam o mineral, enquanto os tratamentos receberam $370 \mathrm{ppb}$. Nos dias $0,11,22$ os animais tiveram o sangue colhido e foram pesados após jejum de 18 horas. Os autores não encontraram diferença nem entre as raças, nem entre os tratamentos nas concentrações plasmáticas de glicose, uréia, albumina, insulina, no consumo de alimentos e na eficiência alimentar. Houve uma tendência do colesterol ser maior nos cordeiros alimentados com cromo. Quando os autores compararam o efeito do tratamento entre as raças, Suffolk teve maiores índices de ácidos graxos insaturados no plasma e de ganho de peso. Os autores não 
ORTUNHO, V.V. Revisão da literatura: mineralização e perfil metabólico em ovinos. PUBVET, Londrina, V. 7, N. 10, Ed. 233, Art. 1537, Maio, 2013.

encontraram diferenças na suplementação com cromo, portanto concluíram que mais trabalhos precisam ser feitos para explorarem o mecanismo de ação do mineral no metabolismo da glicose e dos lipídios.

Mostafa-Tehrani et al. (2006) avaliaram a carcaça de 70 cordeiros da raça Shal alimentados com $0 ; 200 ; 600$ ou $1000 \square \mathrm{g}$ de nicotinato de cromo, enquanto que outros animais receberam 200; 600 ou $1000 \square \mathrm{g}$ de cloreto de cromo. O peso final dos animais e o ganho de peso médio diário não foram afetados pelos tratamentos, porém os animais que receberam o mineral orgânico tiveram maiores pesos na carcaça e menores pesos na gordura cardíaca e peso cardíaco. A adição de $200 \square$ g de cromo orgânico aumentou o peso cardíaco, dos tecidos, rins e pulmões e ainda diminuiu o peso da gordura interna. Os autores concluíram que os resultados mostraram que a adição de cromo, principalmente o orgânico mostrou ser benéfica para melhorar a qualidade de carcaça.

Al-Mufarrej et al. (2008) relatam que estudos prévios têm demonstrado que a suplementação com cromo na dieta de bovinos tem reduzido o estresse dos animais, melhorando o sistema imunológico e o desempenho deles, baseado nisso e sabendo-se que esse mineral potencializa a ação da insulina, os autores pesquisaram a influência do cromo orgânico em 48 cordeiros da raça Naemi que foram transportados em caminhão por uma distância de $1450 \mathrm{~km}$ para simular o estresse por transporte. O grupo controle não recebeu o mineral e os grupos desafios receberam doses de 0,3;0,6 e 0,9 $\mathrm{mg} / \mathrm{kg}$ de cromo orgânico. Todos os animais nos dias 0,21 e 42 foram imunizados com um antígeno. A colheita de sangue era realizada antes do embarque, após o transporte e semanalmente. Ainda nesse trabalho os autores observaram que todas as ovelhas avaliadas, após o estresse, apresentaram elevação da glicemia, do cortisol, da proteína total e da albumina, enquanto que o colesterol diminuiu. Não foi observada diferença na uréia plasmática. Ao compararem os animais suplementados e os que não receberam cromo observou-se que a proteína total, albumina, colesterol total, uréia, cortisol e a glicemia não diferiram entre os grupos, porém a imunidade 
ORTUNHO, V.V. Revisão da literatura: mineralização e perfil metabólico em ovinos. PUBVET, Londrina, V. 7, N. 10, Ed. 233, Art. 1537, Maio, 2013.

humoral e celular foi maior nos tratados com o mineral. Os autores concluíram que a suplementação com cromo pode ser benéfica para reduzir os efeitos do estresse e aumentar a resistência dos animais, porém não foram encontradas diferenças clínicas ou bioquímicas que pudessem ser atribuídas à adição desse mineral na dieta.

Xiaogang et al. (2008) avaliaram a carcaça de 48 cordeiros da raça Dorper x Small-tail Han de 9 semanas de idade, que haviam sido alimentados com diferentes níveis de cromo orgânico: 0, 400, 800 ppb; para avaliarem possíveis interações entre taxa de crescimento, características de carcaça, atividade da insulina e metabolismo de lipídeos. Todos os animais tiveram aumento no ganho de peso. A glicemia não foi alterada por nenhum dos tratamentos, embora a suplementação com o mineral diminuísse a taxa de deposição de gordura intramuscular. A adição de 400 ppb diminuiu os triglicérides, colesterol total, colesterol HDL e a atividade da lipase no tecido subcutâneo. Os autores concluíram que a adição do mineral teve efeitos notáveis na atividade de alguns metabólitos sanguíneos e que o mineral modulou a quantidade de lipídeos no tecido muscular.

Domínguez-Vara (2009) utilizaram 54 carneiros da raça Rambouillet de $27 \pm 4,8 \mathrm{~kg}$ que foram divididos em 6 tratamentos, 3 receberam selênio orgânico e outros 3 tratamentos receberam cromo orgânico em doses diferentes, os objetivos do trabalho foram verificar as diferenças no ganho de peso, características de carcaça e metabólitos sanguíneos. O sangue dos animais foi colhido nas semanas 2, 7 e 11, após jejum e, ao final do experimento 30 animais foram eutanaziados para terem a carcaça avaliada. A suplementação com selênio não afetou os triglicérides, colesterol, glicose, uréia, conversão alimentar e ganho de peso médio diário, mas, aumentou os níveis plasmáticos de T3, T4 e diminuiu o cortisol plasmático. Os animais que não receberam selênio, mas receberam cromo não tiveram o colesterol, uréia, cortisol, T3, T4 afetados pelo mineral, embora tenha havido aumento linear na glicemia, conforme a dose do cromo era maior, sendo também observado efeito quadrático nos triglicérides. Para os animais que receberam os dois 
minerais houve aumento linear dos triglicérides e da insulina, diminuição linear da uréia plasmática, embora a glicemia, o cortisol, T3 e T4 plasmáticos não foram afetados pelo tratamento. Os autores concluíram que o selênio e o cromo interagem entre si modificando as características de carcaça, taxas de crescimento e afetando hormônios e metabólitos sanguíneos de cordeiros.

Dallago et al. (2011) estudaram 24 cordeiros da raça Santa Inês de 22,89 $\pm 2,23 \mathrm{~kg}$ durante 84 dias para avaliarem o efeito da suplementação com cromo orgânico no desempenho dos cordeiros. Os animais foram divididos em 4 grupos que receberam quantidades diferentes do mineral: $0 ; 0,25 ; 0,38$ e $0,5 \mathrm{mg}$ de cromo/animal/dia. Ao final do experimento não foram encontradas diferenças estatísticas no ganho de peso médio diário, peso final dos animais e na taxa de crescimento dos animais.

Lindemann (2007) e Dallago et al. (2011) observaram que os maiores benefícios da suplementação com cromo orgânico são vistos quando há a presença de fatores estressantes como: a gestação, a lactação, trauma físico, doença, transporte, porque o mineral facilita a ação da insulina e relatam que pela possibilidade dos animais de produção terem reduzidos os efeitos maléficos provocados pelo estresse, o uso do cromo orgânico têm atraído a atenção dos produtores, porém pesquisas que avaliem a suplementação com esse mineral nos ovinos ainda são escassas quando compara-se com os trabalhos publicados em humanos e em animais de laboratório.

\section{- Cobre orgânico}

Baseados nos relatos da literatura que os minerais orgânicos possuem maior biodisponibilidade, são absorvidos mais rapidamente que os minerais inorgânicos e sabendo-se que as ovelhas podem desenvolver uma toxicidade ao cobre, Eckert et al. (1999) pesquisaram 30 ovelhas da raça Rambouillet, 15 fêmeas receberam $\mathrm{CuSO}_{4}$ e as demais; proteinato de cobre. Durante o experimento, foram oferecidos 3 níveis do mineral: 10, 20 e 30 $\mathrm{mg} / \mathrm{kg}$. O sangue foi colhido nos dias 28 e 73, após o início do experimento. Os 
ORTUNHO, V.V. Revisão da literatura: mineralização e perfil metabólico em ovinos. PUBVET, Londrina, V. 7, N. 10, Ed. 233, Art. 1537, Maio, 2013.

autores não encontraram diferença estatística entre os grupos no eritrograma, mas a concentração de cobre no fígado foi maior nos animais que receberam o mineral inorgânico. Os autores relataram que durante o experimento os animais não apresentaram sinais de toxidade e acreditam que esse fato devese pelos animais não terem sofrido estresse, por isso, advertiram que cuidados devem ser tomados com o nível deste mineral na dieta.

Um estudo realizado por Hatfield et al. (2001) avaliou os efeitos da suplementação com cobre e zinco na forma orgânica e inorgânica em ovelhas secas Targhee, de 6 anos de idade. Os animais foram divididos nos seguintes grupos: controle que não recebeu suplementação mineral, zinco orgânico, zinco e cobre orgânico, sulfato de zinco e; zinco e cobre na forma de sulfato. Colheu-se sangue nos dias $0,14,28,42$, e 56. Os autores não encontraram interação entre a forma de suplementação com o mineral. As ovelhas que estavam nos grupos tratados apresentaram ganho de peso médio maior que o grupo controle, porém, entre os tratamentos não houve diferença. A atividade da enzima FA tendeu a ser maior nos animais do grupo alimentado com sulfato. Os animais alimentados com os minerais na forma orgânica apresentaram maiores concentrações de zinco e cobre no fígado. A suplementação com cobre tendeu a aumentar a concentração de zinco no fígado das ovelhas, entretanto animais alimentados com altas doses de zinco não tiveram impacto negativo no status do cobre hepático. Os autores concluíram que as ovelhas podem receber altos níveis de zinco na dieta sem que haja efeito negativo ao animal.

Luo et al. (1996) utilizaram cordeiros de aproximadamente 39 $\mathrm{kg}$, divididos em 3 grupos, 14 animais receberam cobre na forma orgânica, 14 receberam sulfato de cobre e 11 receberam dieta sem o mineral. Alguns animais receberam os minerais somente uma vez ao dia, enquanto outros recebiam a mesma quantidade, porém divididas em 6 porções ao longo do dia. No início e ao final do experimento foi realizada biópsia do fígado dos animais. Após as análises, os autores concluíram que os cordeiros alimentados uma vez acumularam mais cobre no fígado que os outros animais, não houve interação 
entre a quantidade de vezes que os animais recebiam o mineral com o tipo de mineral ofertado.

Pal et al. (2010) compararam a influência dos efeitos da suplementação de zinco e cobre, 12 ovelhas foram divididas em 2 tratamentos: zinco e cobre na forma orgânica e o outro grupo recebeu os minerais na forma inorgânica. Não houve diferença no ganho de peso médio diário e na concentração desses minerais na lã entre os grupos. Os autores encontraram que os animais que receberam a forma orgânica tiveram maiores concentrações de zinco e cobre no fígado e no plasma, menores quantidades desses minerais excretados nas fezes também foram encontradas. Os autores relataram que esse experimento consolida a hipótese que os minerais inorgânicos têm menor absorção intestinal, enquanto que os minerais orgânicos são absorvidos rapidamente pelas mucosas, caindo rapidamente na corrente sanguínea. Os autores concluíram que a maior biodisponibilidade dos minerais na forma orgânica reduz o requerimento desses minerais na dieta, diminuindo a eliminação de minerais pelas fezes e deposição no solo.

\section{- Enxofre Orgânico}

Hamilton (2006) estudou os efeitos da adição de enxofre inorgânico e orgânico em 12 carneiros machos adultos, mestiços Santa Inês objetivando avaliar os efeitos dessas suplementações sobre as características seminais dos animais estudados. Os animais foram divididos em 3 tratamentos: dieta sem o mineral, enxofre orgânico e enxofre inorgânico. Colheitas de sêmen, pesagem dos animais e aferição da circunferência escrotal foram feitas semanalmente. Os animais que receberam 0 enxofre apresentaram maiores quantidades de nitrogênio no sêmen, porém não houve diferença entre a forma ofertada do mineral nos parâmetros analisados.

\section{- Selênio Orgânico}

Muñoz et al. (2008) estudaram 2 grupos de ovelhas durante a gestação. Um grupo não recebeu suplementação e o outro recebeu $0,5 \mathrm{mg}$ de 
ORTUNHO, V.V. Revisão da literatura: mineralização e perfil metabólico em ovinos. PUBVET, Londrina, V. 7, N. 10, Ed. 233, Art. 1537, Maio, 2013.

selênio orgânico por dia. O grupo suplementado teve uma melhora na imunidade. Não houve diferença estatística na taxa de prenhez entre os tratamentos e os cordeiros, cujas mães receberam suplementação nasceram com maior vigor, melhor imunidade, maior concentração de selênio no plasma, porém não houve diferença na taxa de mortalidade. Os autores concluíram que a suplementação com selênio durante a gestação afeta positivamente os cordeiros.

Vonnahme et al. (2010) utilizaram 82 ovelhas primíparas da raça Rambouillet, as quais foram separadas em 2 tratamentos no acasalamento: 40 fêmeas receberam selênio na quantidade adequada ( $9,5 \square \mathrm{g} / \mathrm{kg}$ peso vivo), enquanto 42 receberam uma alta quantia do mineral ( $81,8 \square \mathrm{g} / \mathrm{kg}$ peso vivo), que foi fornecido como seleniometionina. Os cordeiros cujas mães receberam maiores quantidades do mineral nasceram mais pesados e maiores. Não houve efeito do selênio no escore corporal materno e no ganho de peso durante a gestação. Os autores concluíram que a suplementação com selênio durante a gestação aumentou as chances dos cordeiros nascerem maiores e mais pesados.

Hall et al. (2012a) com o objetivo de avaliar o selênio orgânico e inorgânico, separaram 240 ovelhas adultas em 8 tratamentos, que receberam o selênio em formas e em quantidades diferentes, sendo que o grupo controle não recebeu o mineral. Os autores encontraram que as ovelhas tratadas tiveram mais selênio no plasma que aquelas que não receberam o mineral. Maiores quantidades do mineral foram encontradas nos animais que receberam o mineral na forma orgânica. A quantidade de selênio no plasma foi semelhante para os animais que receberam uma dose menor que a recomendada de selênio na forma orgânica e para os animais que receberam uma alta dose do mineral, porém na forma inorgânica. Este experimento mostrou que o selênio orgânico possui uma alta biodisponibilidade.

Hall et al. (2012b) realizaram um experimento para avaliarem o quanto que o oferecimento de diferentes quantidades de selênio orgânico e inorgânico podem afetar a qualidade do colostro, para isso separaram 240 
ovelhas adultas em 8 tratamentos, sendo que o controle não recebeu o mineral. Os autores encontraram que o oferecimento do mineral na forma orgânica durante a gestação e lactação propiciou uma maior quantidade de selênio no colostro. Os ordeiros cujas mães receberam o mineral orgânico tiveram maiores quantidades de selênio no plasma e nos músculos.

\section{- Zinco Orgânico}

Hatfield et al. (2002) suplementam 4 grupos de ovelhas Targhee, secas para avaliarem os efeitos da suplementação com zinco orgânico e de vitamina $E$, oferecidos em diferentes quantidades entre os tratamentos. Os autores não encontraram diferenças nas atividades de FA, no ganho de peso e na concentração hepática de zinco, porém, concluíram que altos níveis de zinco na dieta podem prejudicar a função imune e humoral dos animais.

Objetivando estudar a eficácia do zinco no crescimento, ganho de peso, no perfil mineral e na utilização de nutrientes Garg, Mudgal e Dass (2008) avaliaram 18 cordeiros machos da raça Muzaffarnagari. Os animais foram divididos em 3 grupos, na seguinte forma: dieta base que não continha o mineral, dieta base acrescida de $20 \mathrm{mg} / \mathrm{kg}$ de $\mathrm{Zn}$ na forma orgânica e dieta base acrescida de $20 \mathrm{mg} / \mathrm{kg}$ de sulfato de zinco. Os dados encontrados mostraram que os animais que receberam o mineral orgânico apresentaram maior ganho de peso e mais zinco no plasma que os animais dos outros grupos, houve uma melhora no crescimento e na conversão alimentar. Os autores concluíram que a suplementação com zinco na forma quelatada melhorou o desempenho dos animais.

\subsection{BALANÇO ENERGÉTICO NEGATIVO E CETOGÊNESE NA GESTAÇÃO}

A gestação das ovelhas compreende um período de aproximadamente 21 semanas, podendo variar de 140 a 150 dias. Durante este período, várias mudanças ocorrem no organismo materno, entre elas citam-se, as alterações sofridas na composição sanguínea, no sistema 
cardiovascular e mudanças metabólicas (SCHEAFFER et al., 2004). Na verdade, todas estas alterações possuem como objetivos: o ajuste do suprimento de nutrientes para o feto e o preparo do organismo materno para a lactação (BATAVANI; ANSARI; ASRI, 2006).

Pode-se dividir o período gestacional em duas fases, como observado na Figura 3, sendo que a primeira, correspondente aos dois primeiros terços, ou seja, até os 100 dias de gestação. Nesta fase ocorre a diferenciação dos órgãos, tecidos e crescimento do feto em até $30 \%$ de seu peso corporal. Poderá ser fornecida uma alimentação que satisfaça as exigências nutricionais de mantença das matrizes. Porém, a fêmea jamais deverá sofrer restrição alimentar nas primeiras 3 a 4 semanas após a cobertura, para que não ocorra redução nos índices de concepção, comprometimento da implantação do embrião no útero e do desenvolvimento placentário (PILAR; PEREZ; SANTOS, 2002).

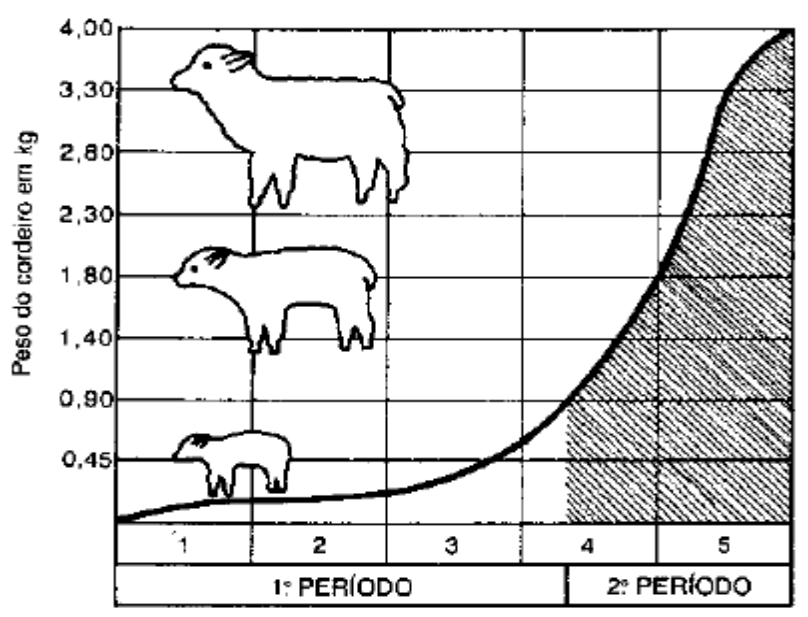

Figura 3 - Desenvolvimento gestacional

Fonte: Minola e Goyenechea (apud Pilar; Perez; Santos, 2002).

Na segunda fase da gestação, período correspondente ao terço final, o feto irá crescer $70 \%$ do seu peso corporal, portanto, as matrizes devem receber a melhor alimentação possível, em quantidade e qualidade (PILAR; PEREZ; SANTOS, 2002). Para que o desenvolvimento do feto seja adequado e 
que a glândula mamária inicie a produção láctea, o requerimento de minerais, de proteína e de energia na matriz é alterado, como exemplo, a necessidade de glicose aumenta em $100 \%$ nas ovelhas carregando dois fetos e de $30-50 \%$ nas que estão prenhes de um (BELL; BAUMAN, 1997).

Nesta fase, porém, acontece a diminuição da ingestão de alimentos em aproximadamente $20 \%$, devido o aumento do volume do útero, que comprime o rúmen (PASTOR; LOSTE; SÁEZ, 2001).

Percebe-se que devido a ingestão baixa de níveis energéticos, seu baixo aproveitamento e a alta demanda de nutrientes provocam um balanço energético negativo com consequente diminuição gradual de glicose sanguínea, diminuição de glicogênio hepático, mobilização de gorduras para serem utilizadas como fonte de energia, podendo haver neste processo a formação de corpos cetônicos com o desenvolvimento de uma patologia conhecida por Toxemia da Prenhez (EHRHARDT et al., 2001; HARMEYER; SCHLUMBOHM, 2008; HUSTED et al., 2008; RESENDE et al., 1999).

Uma vez estabelecido o desequilíbrio energético, o organismo animal tenta manter a glicemia adequada para atender as necesidades do tecidos vitais, do feto e da glándula mamária, para isso, ele promove a gliconeogênse hepática que utiliza como substratos: o propionato, o lactato e o glicerol (HARMEYER; SCHLUMBOHM, 2006).

A gliconeogênese, que é a síntese de glicose a partir de compostos não-carboidratos, tenta satisfazer as necessidades de glicose do organismo quando o carboidrato dietético é insuficiente. Este mecanismo adquire importância crescente durante o jejum, quando o glicogênio hepático se esgota. As vias gliconeogênicas constituem um mecanismo para remover do sangue, o lactato, produzido por músculos e eritrócitos, bem como o glicerol, produzido no tecido adiposo e o propionato, que é um ácido graxo volátil, oriundo da fermentação anaeróbica de carboidratos dietéticos (BEITZ, 1996).

Se ainda a necessidade de glicose não for atendida, as substâncias corporais de reserva, que são os triacilgliceróis, serão metabolizadas (PASTOR; LOSTE; SÁEZ, 2001). Esta reação, que é conhecida 
por lipólise, resulta na formação de glicerol e de ácidos graxos não esterificados, conhecidos também como ácidos graxos livres, que serão transportados pela albumina até o fígado (BEITZ, 1996; CALDEIRA, 2005). Neste órgão, os ácidos graxos não esterificados, poderão seguir 2 vias metabólicas diferentes: síntese de triacilgliceróis e formação de Acetil-CoA no citosol.

Na síntese de triacilgliceróis, no fígado os AGL circulantes podem ser reesterificados, principalmente em triacilgliceróis, fosfolípideos e em ésteres de colesterol, resultando num rápido acúmulo destas substâncias no órgão, quadro conhecido por esteatose hepática (CALDEIRA, 2005; ORTOLANI, 2009).

Já, se a via metabólica seguida for a formação de Acetil-CoA no citosol, os ácidos graxos não esterificados podem ser degradados por um processo de beta-oxidação, que resultará na formação de acetil-CoA e numa grande quantidade de ATP (BEITZ, 1996).

A literatura relata que 0 acetil-CoA também pode seguir duas vias metabólicas que são entrar no ciclo de Krebs ou formar corpos cetônicos.

Se a rota seguida for entrar no ciclo de Krebs: o acetil-CoA se unirá com oxaloacetato e acabará entrando no ciclo de Krebs, originando água e liberando $\mathrm{CO}_{2}$ (ORTOLANI, 2009).

A formação de corpos cetônicos acontece quando a quantidade de oxaloacetato é insuficiente, exemplo: quando é metabolizada muita gordura, falta oxaloacetato para a união com a Aceti-CoA, sendo que 2 moléculas desta substância ao se condensarem formam os corpos cetônicos: acetoacetato, acetona e $\beta$-hidroxibutirato, que também é conhecida por 3hidroxibutirato ou BHB (BRUSS, 1997).

O acetoacetato é o corpo cetônico central, pois os outros 2 originam-se dele, como pode ser observado na Figura 4. A acetona, que é um composto volátil, produzida por descarboxilação espontânea do acetoacetato, é exalada quando em excesso, e pode se tornar um sinal clínico a ser pesquisado (FUKAO; LOPASCHUK; MITCHEL, 2004). 
Já o $\beta$-hidroxibutirato, que é produto da redução do acetoacetato, não é volátil e é quimicamente estável, e segundo Kaneko (1997) este é o corpo cetônico presente em maior quantidade.

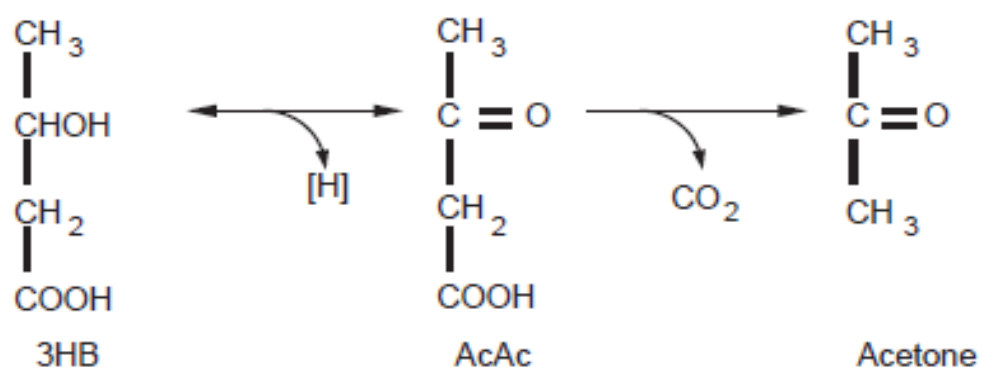

Figura 4 - Corpos Cetônicos.

Fonte: Fukao, Lopaschuk e Mitchel (2004).

Pethick e Lindsay (1982), Fukao, Lopaschuk e Mitchell (2004) e Riccó (2004) afirmam que a produção de corpos cetônicos é um mecanismo comumente utilizado e produzido pelo organismo dos ruminantes e que ao serem alimentados com uma dieta equilibrada, o butirato, produzido na fermentação microbiana, é metabolizado na sua maior parte para $\beta$ hidroxibutirato nos epitélios retículo-ruminal e omasal. A fração restante passa para o sangue portal, sendo captado pelo fígado e igualmente transformado em $\beta$-hidroxibutirato e em acetoacetato (CALDEIRA, 2005).

Quando há falta de energia nos tecidos periféricos, especialmente na musculatura esquelética, os corpos cetônicos podem ser utilizados para suprir em até $30 \%$ a demanda de energia necessária, a partir da oxidação destas substâncias em $\mathrm{CO}_{2}$, em suas mitocôndrias (BEITZ, 1996).

Durante a cetonemia, alguns tecidos como coração, músculo esquelético, rins, tecidos não fetais e glândula mamária podem utilizar os corpos cetônicos para produção de energia, porém o feto e o cérebro não, os quais necessitam da glicose, como fonte energética (BRUSS, 1997). 


\subsubsection{Toxemia da Prenhez}

Toxemia da Prenhez, que também pode ser chamada de cetose e pré-eclâmpsia, é um distúrbio metabólico, primeiramente descrito em 1854 por Seaman, que observou a ocorrência da patologia em ovelhas gordas que sofriam de jejum temporário, condicionado pelos tratadores que desejavam que as fêmeas deveriam emagrecer para não terem problemas no parto (LINDSAY, 2006).

É uma patologia que ocorre comumente nas últimas 6 semanas de gestação, sendo caracterizada na análise de sangue e de urina por cetonemia, cetonúria, hipoglicemia nos estágios iniciais e normo ou hiperglicemia nos estágios avançados, aumento da concentração de ácidos graxos livres no plasma e acidose, pois, o $\beta$-hidroxibutirato e o acetoacetato reduzem a concentração de $\mathrm{HCO}_{3}^{-}, \mathrm{Cl}^{-}, \mathrm{Na}^{+}$, e $\mathrm{K}^{+}$(KABAKCI et al., 2003; KANEKO,1997).

No estudo realizado por Kabakci et al. (2003), análises de sangue e de urina foram realizadas em fêmeas gestantes saudáveis e em fêmeas com a Toxemia da Prenhez. As acometidas pela patologia tinham hipoglicemia e o colesterol HDL e LDL estavam menores que o das saudáveis. A concentração de triglicérides, AST e ALT estavam menores quando se comparou com os animais controle.

Yarim e Ciftci, (2009) por saberem dos prejuízos causados pela Toxemia da Prenhez e também por saberem que análises sanguíneas são úteis para seu diagnóstico, estudaram 27 ovelhas de 3-5 anos da raça Karayaka que estavam com 18-20 semanas de gestação. Entre estes animais 15 apresentavam a patologia enquanto, as outras fêmeas estavam saudáveis. Colheu-se sangue de todos os animais. Os valores de proteína total e albumina apresentaram-se maiores para as saudáveis, AST, ALT, GGT, uréia e creatinina foram maiores nas fêmeas com Toxemia da Prenhez, mostrando que na patologia estudada há uma grande perda na função renal e hepática. 
Entre os sinais clínicos que merecem destaque estão: a perda de peso, anorexia, apatia, desorientação, relutância em caminhar, ranger de dentes, amaurose, meneios de cabeça, andar em círculos, salivação excessiva, decúbito esternal (KABAKCI et al., 2003). Estes sinais nervosos ocorrem devido à diminuição da glicose no cérebro, sendo por isso, chamados de encefalopatia hipoglicêmica, que podem ser irreversíveis nos casos severos de Toxemia (ANDREWS; HOLLAND-HOWES; WILKINSON, 1996).

O aumento de corpos cetônicos no plasma inibe a formação de glicose no fígado, aumentando ainda mais a hipoglicemia e sabe-se que a severidade da doença está relacionada com a extensão e duração da cetonemia (HARMEYER; SCHLUMBOHM, 2008).

Em alguns animais, os sinais clínicos podem desaparecer após cesariana realizada nas fases iniciais da doença ou em casos que acontecem aborto, pois há a diminuição da demanda de glicose (SARGISON et al., 1994).

Os sinais clínicos podem aparecer em animais com condição corporal normal, mas que estejam com patologias que culminem com perda ou diminuição de apetite; em animais superalimentados e em subalimentados durante a gestação. Sendo que as obesas possuem maior risco de desenvolverem a patologia (KABAKCI et al., 2003; ORTOLANI, 2009; SCHLUMBOHM; HARMEYER, 2008). Há também fatores individuais que interferem no surgimento da enfermidade, predispondo alguns animais ao problema, o que está mais ligado à capacidade ou não que algumas fêmeas têm em sintetizar e manter os teores de glicose dentro de limites suportáveis, assim como utilizar a glicose pelos tecidos periféricos (ORTOLANI, 2009).

A Toxemia da Prenhez afeta mais as fêmeas com maior idade e as que carregam fetos múltiplos (ANDREWS; HOLLAND-HOWES; WILKINSON, 1996). Grandes perdas econômicas são relatadas por causar também abortos e até mesmo morte das fêmeas gestantes. A taxa de mortalidade é alta, podendo ser de $80 \%$ e somente $20 \%$ das fêmeas sem tratamento se recuperam (YARIM; CIFTCI, 2009). 
Schlumbohm e Harmeyer (2008) estudaram 3 ovelhas da raça Texel prenhes de gêmeos e 3 Black German Face prenhes de um, as amostras de sangue foram colhidas após jejum over-night, após refeição e após indução de hipercetonemia, que aconteceram no período seco, 10 dias antes do parto e 2 semanas após parto. A concentração de glicose após refeição não apresentou diferença entre os períodos reprodutivos e as prenhes de gêmeos tinham menores valores séricos de glicose que as outras. A aplicação do estresse hipoglicêmico diminuiu a glicemia em todos os períodos reprodutivos. Os resultados encontrados nesse experimento mostram que fêmeas prenhes de 2 fetos são mais sensíveis ao estresse hipoglicêmico que ocorre no final da gestação pois nesta fase há uma menor produção deste metabólito, mostrando serem essas as ovelhas mais susceptíveis ao desenvolvimento da Toxemia da Prenhez.

A etiopatogenia ainda não está completamente elucidada (YARIM; CIFTCI, 2009). Acredita-se a Toxemia da Prenhez ocorra pela inabilidade das ovelhas gestantes de gêmeos atenderem a demanda energética exigida pela unidade feto-placenta e há relatos na literatura que citam que durante a gestação, principalmente nas prenhes de 2 fetos, ocorre uma redução na taxa extração de beta-hidroxibutirato dos tecidos periféricos, quando se compara com animais no período seco e lactantes. Este fato poderia explicar o porquê ocorre o desenvolvimento de uma patologia durante a gestação das ovelhas, quando ainda a taxa de formação de corpos cetônicos não atingiu seu máximo, que é durante a lactação (HARMEYER; SCHLUMBOHM, 2006).

Mas, sabe-se que a doença está associada com o distúrbio no metabolismo de gordura e de carboidrato, pois como relatado anteriormente, durante a gestação ocorre uma grande demanda de energia requerida para o crescimento do feto provocando um desequilíbrio energético, resultando em aumento da concentração de ácidos graxos não insaturados no sangue, cetonemia, acidose metabólica, prejuízos nas funções renais e hepáticas, com 
a condição de fígado gorduroso (HARMEYER; SCHLUMBOHM, 2006, 2008; PALMQUIST; MATTOS, 2006).

Kabakci et al. (2003) citaram que o fígado gorduroso é um sinal característico nas fêmeas superalimentadas com a patologia, relataram também que o órgão apresentará uma severa degeneração e acúmulo de lipídeos tornando-se amarelo, sendo que no estudo realizado pelos autores este achado foi o mais característico e mais visto nos animais necropsiados acometidos pela patologia.

O diagnóstico da Toxemia da Prenhez é feito com a análise dos sinais clínicos e é concluído com a mensuração de corpos cetônicos no sangue e na urina, muitos autores citam que a avaliação da concentração de glicose sanguínea pode auxiliar no diagnóstico (MAVROGIANNI; BROZOS, 2008).

Como o prognóstico da enfermidade, na maioria dos casos é mau, deve-se centrar esforços para prevenir seu aparecimento nos rebanhos. O objetivo deve ser a alimentação correta nos diferentes estágios da gestação, levando-se em consideração o custo-benefício. Uma maneira de evitar a ocorrência desta patologia é a realização do perfil metabólico com a dosagem de $\beta$-hidroxibutirato no final da gestação, a análise da atividade de GGT pode ser feita e indicará a função hepática, se houver tendência de ocorrer à patologia, os valores deste parâmetro poderão estar acima de $30 \mathrm{UI} / \mathrm{L}$ (ORTOLANI, 2009). Recomenda-se também a análise da atividade da FA, pois nos casos severos, ela pode estar aumentada, embora seja pouco específica para distúrbios hepáticos em ovinos (PASTOR; LOSTE; SÁEZ, 2001).

Lamentavelmente, a Toxemia da Prenhez está ocorrendo com maior frequência prejudicando o crescimento da atividade e provocando uma diminuição na rentabilidade da empresa pecuária (WITTNER, 2000).

Geralmente, a maioria das doenças metabólicas e nutricionais tem um efeito de difícil percepção e limitam a produção animal de modo persistente, causando diminuição na rentabilidade da pecuária. É importante dispor de métodos de diagnóstico preventivos, que permitam manter um controle sanitário nutricional dos animais por meio de análises simples, de 
baixo custo e que possam ser realizados preferencialmente em amostras de leite, sangue e urina para facilitar a colheita e manejo. O uso do perfil metabólico neste sentido vem sendo estimulado por pesquisas e as tendências nos próximos anos é a ampliação do seu uso e a procura por marcadores bioquímicos mais específicos que possam aproximar cada vez mais o perfil ao estado metabólico real dos rebanhos, a fim de aumentar a eficiência produtiva (GONZÁLEZ, 2000).

\subsection{PERFIL METABÓLICO E ANÁLISE DO HEMOGRAMA}

O termo Perfil Metabólico foi proposto por Payne, na Inglaterra, em 1970 e surgiu como método auxiliar no diagnóstico das doenças de produção. Inicialmente, eram análises sanguíneas em indivíduos de rebanhos bovinos leiteiros. Atualmente, outros fluidos também são analisados como o leite, urina e saliva (RICCó, 2004).

O número de variáveis potencialmente mensuráveis no perfil metabólico é ilimitado. Mas, na prática, opta-se avaliar parâmetros que se tenham conhecimentos sobre a fisiologia e a bioquímica, para que a interpretação dos resultados seja facilitada (WITTWER, 2000). Além disso, é importante que o equipamento e a técnica usados para a determinação dos parâmetros sejam economicamente viáveis (RUSSEL; ROUSSEL, 2007).

O sangue foi sempre o fluido mais utilizado para a determinação da concentração de indicadores do estado nutricional ou metabólico, tanto pela qualidade da informação que fornece, como pela facilidade de colheita (CALDEIRA, 2005).

O Perfil metabólico é uma ferramenta que avalia vários sistemas, detecta lesões teciduais e transtornos no funcionamento de órgãos (GONZÁLEZ; SCHEFFER, 2003). Sendo essencial para estabelecer os parâmetros iniciais de tratamento, confirmar diagnóstico, determinar prognóstico, planejar a terapêutica e acompanhar o tratamento (ANTUNOVIĆ; SENČIC; SPERANDA, 2001; RUSSEL; ROUSSEL, 2007). 
Identificar alterações no metabolismo das ovelhas durante a gestação para prever e evitar a ocorrência de doenças, como Toxemia da Prenhez e de outros problemas pré e pós-parto, são algumas das vantagens em se determinar o perfil metabólico nessa espécie (BALIKCI; YILDIZ; GÜRDOGAN, 2007).

A avaliação dos parâmetros sanguíneos também, permite aferir a adequação dos planos alimentares implementados na exploração, possibilitando correções imediatas ou alterações das estratégias nos ciclos produtivos seguintes, sendo útil então, para aumentar a produtividade do rebanho (CALDEIRA, 2005).

Embora existam muitas variações entre os laboratórios, o perfil metabólico de um ruminante geralmente inclui, a análise de: glicose; lactato; uréia; creatinina; eletrólitos como, sódio, cloretos e o potássio; enzimas hepáticas, que incluem a dosagem de ALT, GGT e AST; bilirrubinas; minerais como o cálcio, fósforo e magnésio; e dosagem das enzimas musculares, como a creatina quinase e AST. Outros parâmetros podem fazer parte da rotina de alguns laboratórios e serem incluídos na análise, como a dosagem de: ácidos biliares, amônia, colesteróis, triglicérides e ácidos graxos não esterificados (RUSSEL; ROUSSEL, 2007).

Muitos autores recomendam incluir na análise outros parâmetros como: frequências cardíaca, respiratória, urinálise e avaliação do hemograma que também tem se tornado essencial na investigação de problemas clínicos em ovinos, sua interpretação juntamente com o perfil metabólico auxilia no diagnóstico e o prognóstico de algumas patologias (ANTUNOVIĆ; SENČIC; SPERANDA, 2001; CALDEIRA, 2005; POLIZOPOULOU, 2010).

A possibilidade de análises que podem ser feitas no perfil metabólico é ampla, o que determina a realização de uma análise em detrimento a outra é a rotina do laboratório, disponibilidade de equipamentos e a suspeita clínica (RUSSEL; ROUSSEL, 2007).

Os resultados das análises sanguíneas dependem da própria colheita, preparo das amostras e transporte das mesmas. O sangue deve ser 
ORTUNHO, V.V. Revisão da literatura: mineralização e perfil metabólico em ovinos. PUBVET, Londrina, V. 7, N. 10, Ed. 233, Art. 1537, Maio, 2013.

colhido quando os animais estiverem calmos, com contenção correta para que os resultados não sejam alterados devido à liberação de hormônios esteróides e da epinefrina, evita também que o sangue sofra hemólise com a produção de artefatos (CALDEIRA, 2005; POLIZOPOULOU, 2010).

A importância das análises sanguíneas como meio semiológico, auxiliando os veterinários a estabelecerem diagnósticos, firmarem prognósticos e acompanharem os tratamentos das inúmeras enfermidades que atingem os animais domésticos é reconhecida e consagrada mundialmente (VIANA et al., 2002). Entretanto, para que esses objetivos possam ser alcançados e utilizados na plenitude, tornou-se fundamental o conhecimento dos valores de referência dos animais sadios criados no Brasil, bem como dos fatores causadores de suas variações, como alimentação, nível de estresse, estado reprodutivo, raça, idade, sexo dos animais, entre outros, devido à escassez de resultados encontrados na literatura.

Russel e Roussel (2007) relatam que um dos conceitos mais importantes num laboratório de patologia clínica é o intervalo de referência, que representa valores que se espera obter em animais sadios, sendo extremamente importante na interpretação de resultados. Muitas vezes, os valores encontrados podem estar fora do chamado valor de referência, sendo assim atribuído a uma patologia, porém deve-se considerar sempre a possibilidade do valor encontrado ser normal para aquele animal ou rebanho. Por isso, que a definição de valores de referência não é simples, pela dificuldade em estabelecer em biologia, uma fronteira concreta entre o que é considerado normal e o que é uma disfunção ou patologia (CALDEIRA, 2005).

Deve-se ter em mente que o intervalo de referência é calculado para incluir $95 \%$ de uma população saudável, assim $5 \%$ de uma população também saudável tem seus valores fora do intervalo por tanto, quando se realiza o perfil metabólico de um animal ou rebanho e incluí-se a análise de muitos testes, a probabilidade do resultado de pelo menos um deles estar fora do intervalo é de 5\%, então cuidado deve se ter nas interpretações (POLIZOPOULOU, 2010; RUSSEL; ROUSSEL, 2007). 
Quando os pesquisadores colhem várias amostras de um grupo de animais ao longo de um determinado tempo, podem-se encontrar grandes variações nos resultados sem que sejam consideradas patologias, pois pode ter havido variações na alimentação; variações hormonais; mudanças no estado reprodutivo dos animais; regulação da homeostase, como formação e reabsorção de ossos. Nestes casos em que muitas variações são observadas nas análises, mas não são encontradas causas fisiológicas nem patológicas para tais alterações; Braun, Trumel e Bézille (2010) sugerem que diferentes intervalos de referência sejam utilizados na análise desses resultados.

Por isso, a correta interpretação de qualquer análise do perfil metabólico e do hemograma é complexa e o pesquisador deve considerar que a grande variação dos valores encontrados numa análise pode ter ocorrido devido fatores como raça, idade, nível de produção, manejo, clima, sexo e estado fisiológico dos animais (GONZÁLEZ; SCHEFFER, 2003).

Ao analisar as variações que podem existir ao se trabalhar com raças diferentes, Tibbo et al. (2005) estudaram o perfil hematológico de 377 ovinos saudáveis na Etiópia, os quais pertenciam a 3 raças nativas. Houve efeito da raça sobre toda a série eritrocitária, cujos valores nas raças nativas mostraram ser maiores que os das raças exóticas. Enquanto que o sexo dos animais não interferiu nos parâmetros leucocitários e eritrocitários. Houve uma diminuição nos linfócitos e aumento do número de neutrófilos, conforme a idade dos animais aumentava.

Kent (1997) relatou que animais transportados por longos períodos sofrem estresse devido às condições das estradas, dos barulhos, da duração da viagem, privação de água e comida. Sendo assim, nesses animais alguns parâmetros sofrem alterações como frequência cardíaca e respiratória, concentrações de cortisol, glicose, entre outros. O autor recomenda observar se há danos musculares e para isso aconselha o monitoramento da creatina kinase, observar se há presença de desidratação com a determinação do hematócrito e de eletrólitos plasmáticos, os efeitos do jejum podem ser investigados pela dosagem de beta- hidroxibutirato, ácidos graxos livres e 
uréia. Ainda neste trabalho, o autor concluiu que é importante que os animais sejam transportados com o mínimo de estresse para que sejam minimizadas as injúrias sofridas e que assim, melhore o bem estar dos animais e que suas carcaças sejam melhores aproveitadas.

A alimentação que os animais recebem também podem alterar os resultados dos parâmetros sanguíneos. Animais que recebem dieta rica em carboidratos possuem um aumento na concentração de propionato e hiperinsulinemia (ARAI, 2001 apud TANAKA et al., 2008). A redução dos níveis de uréia plasmática pode ocorrer pela diminuição da produção, como em casos de redução da proteína dietética e hipoproteinemia (LOPES; BIONDO; SANTOS, 2007). Enquanto que, um nível de uréia alto indica excesso de proteína ou um déficit energético (RICCÓ, 2004).

Eshratkhah et al. (2010) mostraram que além do sexo dos animais estudados, uma outra variável que também deve ser levada em consideração nas interpretações dos resultados do perfil metabólico é a idade dos animais, pois há mudanças fisiológicas e endocrinológicas que ocorrem em cada fase da vida.

A literatura relata que os anticoagulantes usados nas colheitas de sangue também podem interferir nos resultados e para isso, Mohri e Rezapoor (2009) verificaram a eficiência do uso do soro em relação ao plasma. Foram colhidas amostras de 10 ovelhas saudáveis da raça Baloochi, o sangue foi colocado em tubos com heparina, EDTA, citrato e em tubos sem anticoagulante. Os autores encontraram que a heparina foi o anticoagulante que menos alterou os parâmetros ao se comparar com o soro, mesmo tendo aumentado o valor da albumina. Diferenças significantes foram observadas nas concentrações de glicose, creatinina e ALT quando os autores compararam os valores obtidos na análise do soro com os obtidos com citrato. O uso do EDTA causou várias alterações nos valores de AST e ALT em comparação com o soro. Este estudo comprovou que para se determinar o perfil bioquímico de ovinos o soro é que deve ser utilizado. 
O perfil metabólico pode ser utilizado para melhorar os índices produtivos e reprodutivos da ovinocultura, na adoção de medidas profiláticas e ainda, no conhecimento das alterações que acontecem nos vários períodos produtivos e reprodutivos (ANTUNOVIĆ et al., 2002). Sua análise é extremamente importante e há muita pesquisa para ser realizada nesse campo, de modo a tentar minimizar as principais dificuldades atualmente encontradas, como a interpretação dos resultados e a pequena quantidade de resultados disponíveis na literatura (RICCÓ, 2004).

Segundo Eshratkhah et al. (2011) alguns estudos que determinem o perfil metabólico nos ovinos estão sendo realizados porém, na maioria deles não estão bem especificados os detalhes dos animais; como raça, manejo e idade; os métodos estatísticos usados para determinar os limites de referência são questionáveis, trazendo um prejuízo na comparação e observação clínica dos resultados obtidos pelos outros autores.

Eshratkhah et al. (2011) relataram ainda que, segundo recomendações internacionais, os valores de referência devem ser produzidos e validados por cada laboratório, pois cada um utiliza uma metodologia diferente e geralmente analisa sangue de animais da região próxima de onde se situa o laboratório, facilitando assim, a interpretação dos resultados. Esta recomendação é especialmente importante na análise do perfil metabólico de rebanho saudáveis.

$\mathrm{Na}$ literatura há recomendações de que quando os dados não estão disponíveis ou são escassos, os valores de referência usados devem ser de zonas climáticas e de grupos de animais similares (GONZÁLEZ; SCHEFFER, 2003; TIBBO et al., 2005).

No Brasil os resultados ainda são escassos, dificultando à clínica e um maior entendimento sobre os animais criados no país, então de forma notória, há necessidade da realização de estudos para se determinar os valores de referência do perfil bioquímico dos ovinos criados nas condições brasileiras de manejo e alimentação, bem como a avaliação dos fatores de variação sobre os valores sanguíneos. Entre esses fatores merece destaque aqueles 
ORTUNHO, V.V. Revisão da literatura: mineralização e perfil metabólico em ovinos. PUBVET, Londrina, V. 7, N. 10, Ed. 233, Art. 1537, Maio, 2013.

relacionados à gestação, à parição, ao puerpério e alimentação, justificandose, desta maneira, a realização dessa pesquisa.

\subsubsection{Perfil metabólico durante a gestação e lactação}

Gunter et al. (1990) utilizaram 8 ovelhas da raça Suffolk com peso inicial de 85,7Kg; 4 não estavam prenhes nem lactantes e 4 foram acompanhadas durante o final da gestação com 102, 118 e 132 dias e com 14 dias e 32 dias de lactação; para determinar o efeito da gestação e lactação na função digestória e na concentração de uréia. Os autores encontraram que a taxa de passagem de alimento em animais prenhes foi menor do que nos não prenhes, mostrando que no final da gestação é ingerido menos alimento. Não foram encontradas diferenças estatísticas na proporção entre os ácidos graxos voláteis nas fêmeas prenhes. A concentração de uréia foi afetada pelo estado fisiológico do animal, sendo que, as prenhes e as lactantes tiveram menores concentrações que as secas.

Charismiadou, Bizelis e Rogdakis (2000) estudaram 34 ovelhas da raça Chios de 3 anos de idade durante a gestação, que estavam divididas em 2 grupos, um foi superalimentado recebendo $110 \%$ do requerido de vitaminas, minerais e proteínas; enquanto o outro, apenas $90 \%$. Durante os últimos 10 dias de gestação, as fêmeas foram pesadas e tiveram o sangue colhido. As fêmeas do grupo superalimentado tiveram maior peso e a concentração de glicose plasmática tendeu a ser maior neste mesmo grupo, porém as fêmeas subnutridas tiveram maiores valores de beta- hidroxibutirato nos últimos 10 dias de gestação. Foi observado que nos dias de colheita, para ambos os grupos, os valores de beta- hidroxibutirato foram aumentando. Os autores concluíram que até mesmo uma leve subnutrição durante a gestação pode causar consideráveis mudanças no metabolismo, principalmente no tecido adiposo, para tentar atender a demanda exigida.

Objetivando estudar as alterações sanguíneas que ocorrem durante os períodos reprodutivos de ovelhas, El-Sherif e Assad (2001) 
ORTUNHO, V.V. Revisão da literatura: mineralização e perfil metabólico em ovinos. PUBVET, Londrina, V. 7, N. 10, Ed. 233, Art. 1537, Maio, 2013.

utilizaram 18 animais da raça Barki, pesando 49,8kg em média, com 3-4 anos de idade, sendo que 12 estavam prenhes e o restante, no período seco. Foram realizadas 11 colheitas de sangue de cada animal, sendo que a primeira foi realizada antes da cobertura. Os autores analisaram o eritrograma, glicose sanguínea, AST, ALT, proteína total, albumina, uréia e creatinina. Na lactação os valores de glicose, ALT, uréia, creatinina, proteína total e albumina compararam-se aos obtidos nas ovelhas secas. Os valores de AST e ALT aumentaram significativamente, a partir da segunda semana de gestação. A albumina e a proteína total tiveram um pico na $6^{\text {a }}$ semana de gestação, caindo seus valores na $16^{a}-18^{a}$ semana, a uréia e a creatinina aumentaram significativamente após a $10^{\mathrm{a}}-12^{\mathrm{a}}$ semana. Os autores concluíram que o metabolismo das ovelhas se adapta de acordo com o status fisiológico do animal, citaram que a concentração de hemoglobina que aumentou durante a gestação para melhorar a entrada de oxigênio e concluíram que os resultados mostram a necessidade dos animais terem uma boa nutrição, especialmente de proteína durante a gestação e lactação.

Antunović et al. (2002) objetivaram verificar se havia influência da estação do ano no desempenho reprodutivo e no perfil metabólico de 20 ovelhas da raça Würtemberg com 4 anos de idade, as quais foram acompanhadas desde a gestação até 60 dias de lactação. Para aquelas ovelhas que estavam lactantes no verão foram encontrados maiores quantidade de $\mathrm{Ca}$, $\mathrm{K}, \mathrm{Cl}$ e Fe plasmáticos. No verão, também foi maior a concentração de uréia e proteínas totais, durante o final da gestação e lactação. Enquanto, que a concentração de colesterol plasmático não diferiu entre as estações, mas apresentou maiores valores durante a gestação, fato este que pode ser explicado pela mobilização das lipoproteínas do fígado durante esta fase. A proteína total não variou entre os períodos reprodutivos. Os autores concluíram que as alterações encontradas indicam a necessidade de realizar a monitoração do perfil metabólico, tendo como objetivo, verificar o status metabólico do animal, adotar medidas profiláticas para evitar perdas reprodutivas e produtivas, aumentando assim a produtividade. 
Ribeiro et al. (2004) estudaram 64 ovelhas Border Leicester $x$ Texel. Amostras de sangue de ovelhas vazias, de ovelhas que estavam no início, meio, final da gestação e na lactação foram colhidas para que fossem avaliadas as mudanças metabólicas durante esses períodos. Os valores de proteína total plasmática, globulina plasmática, albumina plasmática, uréia plasmática e colesterol plasmático mantiveram-se dentro dos valores de referência para a espécie, embora apresentassem uma redução com o avanço da gestação e da lactação. Enquanto que os valores plasmáticos de Ca e $\mathrm{P}$ mantiveram-se abaixo dos valores de referência para ovinos. Ao se compararem os valores obtidos nas ovelhas secas e gestantes não foi encontrada diferença em nenhum dos parâmetros. Níveis críticos de glicose foram detectados no final da gestação e início da lactação, coincidindo com os valores mais altos de beta-hidroxibutirato. Os autores concluíram que ovelhas criadas em regime extensivo no Rio Grande do Sul podem apresentar deficiências minerais e energéticas que podem levar a uma ocorrência de doença metabólica, limitando seu potencial reprodutivo.

Willians et al. (2004) colheram sangue de 30 ovelhas Gulf Coast Native e 41 Suffolk que estavam com 100 dias de gestação para avaliarem o perfil metabólico e não encontraram diferença na concentração de glicose plasmática ao se compararem as duas raças, porém encontraram maiores valores estatisticamente de albumina plasmática, uréia, insulina e tiroxina plasmática para as fêmeas Suffolk. Os resultados encontrados de uréia e albumina nesse trabalho estão dentro dos valores normais, indicando um aceitável status nutricional para ambas as raças. Os autores concluíram que há pequenas diferenças na sensibilidade da insulina entre as duas raças estudadas, porém não houve diferença no metabolismo da glicose.

Brito et al. (2006) realizaram um trabalho para estudar a variação dos perfis metabólico e hematológico em 14 ovinos leiteiros da raça Lacaune criados em confinamento na Serra Gaúcha. Amostras de sangue foram colhidas das seguintes categorias: ovelhas vazias; aos 60, 90 e 120 dias de gestação e aos 7, 30,60 e 140 dias de lactação. A uréia plasmática 
mostrou diferença entre a gestação e a lactação, sendo maior com 90 dias de gestação. Os valores de glicose diminuíram e os de beta-hidroxibutirato aumentaram no final da gestação. Com o avanço da lactação, houve diminuição da glicose plasmática e aumento do colesterol. Os parâmetros hematológicos não mostraram diferença nos períodos fisiológicos estudados, com exceção dos neutrófilos segmentados, que aumentaram com o avanço da gestação. Os autores concluíram que os dados encontrados servem como referência para ovelhas desta raça criadas no Brasil, mostraram também que o perfil metabólico apresenta maiores variações no final da gestação e início da lactação, que correspondem aos momentos de maior exigência metabólica.

Harmeyer e Schlumbohm (2006) estudaram 7 ovelhas, das quais 3 eram da raça Texel e estavam prenhes de 2 fetos e 4 da raça German Black Face tendo uma fêmea prenhe de gêmeos. As ovelhas foram estudas durante a gestação, lactação e período seco. Todas as fêmeas usadas no experimento estavam saudáveis e com idade superior a 3 anos. As que carregavam gêmeos apresentaram beta-hidroxibutirato significativamente maior que as fêmeas que tinham um feto, durante o último mês de gestação e durante a lactação. Os valores de beta-hidroxibutirato diferiram entre os estados reprodutivos, sendo que no período seco este parâmetro foi menor que nos outros períodos estudados.

Batavani, Ansari e Asri (2006) estudaram 10 ovelhas Makuii no diestro e durante $\circ 8^{\circ}, 14^{\circ}, 28^{\circ}, 45^{\circ}, 60^{\circ}, 90^{\circ}, 125^{\circ}$ e $145^{\circ}$ dia de gestação para avaliarem alterações na concentração de proteínas no soro e encontraram uma diminuição significativa de proteína total e de albumina no $145^{\circ}$ dia de gestação, quando se comparou com a pré-gestação e os outros períodos gestacionais. Os autores concluíram que as diminuições desses parâmetros no final da gestação devam ser consequência do aumento da taxa metabólica basal materna, do rápido crescimento do feto que sabidamente ocorre no final da gestação e da transformação da albumina, das imunoglobulinas e dos aminoácidos do soro para a produção do colostro. 
Balıkcı, Yıldız e Gürdogan (2007) estudaram 30 ovelhas com idade média de 3 a 5 anos da raça Akkaraman, 15 estavam prenhes de 1 e as outras 15 de gêmeos. Os autores realizaram durante os 60,100 e 150 dias de gestação e após 45 dias do parto, o perfil metabólico desses animais e observaram menores valores de glicose sanguínea nos 100 e 150 dias de gestação, comparados com os outros períodos em ambos os grupos de ovelhas, e menores valores de proteína total e uréia também foram encontrados nos 150 dias de gestação. Enquanto que colesterol plasmático e triglicérides aumentaram no final da gestação e os autores acreditam que este aumento foi devido uma diminuição da resposta à insulina, a qual sabidamente ocorre nesta fase, que age diretamente no tecido adiposo. Os autores concluíram que a magnitude das alterações metabólicas foram maiores nas ovelhas prenhes de gêmeos.

Karapehlivan et al. (2007) realizaram uma pesquisa em 10 ovelhas saudáveis da raça Tuj, com média de 2 anos de idade para verificarem as alterações que ocorrem na lactação. As colheitas de sangue foram realizadas com 1 e 30 dias de lactação e no período seco. A uréia apresentou maiores valores no $30^{\circ}$ dia de lactação que nos outros períodos estudados. A proteína total apresentou-se maior no período seco, enquanto que a albumina foi significativamente menor neste período. A concentração de triglicérideos no período seco foi maior que nos outros períodos e os maiores valores de glicemia foram encontrados na lactação. Os autores concluíram que as alterações sanguíneas que ocorrem durante a lactação alteram os parâmetros bioquímicos mostrando a importância da realização de mais estudos nesta área.

Husted et al. (2008) investigaram alguns parâmetros sanguíneos em 12 ovelhas Shropshire primíparas que tinham sido acompanhadas desde a vida pré-natal. O sangue destes animais foi colhido nos dias, $-70,-28,-21$, $-14,-7$ pré-parto, no dia do parto, 7, 14, 21, 28, 42 e 56 pós-parto. Todas as ovelhas apresentaram um aumento da glicemia durante o final da gestação. Uréia diminuiu durante as 3 últimas semanas de gestação. Concentração de 
ORTUNHO, V.V. Revisão da literatura: mineralização e perfil metabólico em ovinos. PUBVET, Londrina, V. 7, N. 10, Ed. 233, Art. 1537, Maio, 2013.

beta-hidroxibutirato permaneceu estável, mas apresentou um aumento gradual durante a lactação, alcançando um pico com 42 dias após o parto. Os autores mostraram que, como esperado, a gestação é um período que muitas alterações nos parâmetros sanguíneos ocorrem.

Tanaka et al. (2008) objetivaram mensurar a atividade das enzimas hepáticas e as relacionadas com a gliconeogênese, glicólise e síntese de ácidos graxos no plasma de 400 ovelhas gestantes Romney, separadas em 2 grupos que foram sub e superalimentadas a partir do $20^{\circ}$ dia de gestação. Quando as ovelhas estavam com aproximadamente 140 dias de gestação, 5 fêmeas de cada grupo foram eutanaziadas e avaliadas. Os autores encontraram menores pesos e menor concentração de lactato nos animais subalimentados, enquanto que não foi encontrada diferença estatística entre os grupos para os valores de glicose, proteína total, triglicérides, colesterol, AST. Os autores concluíram que a alimentação restrita não influenciou a concentração dos metabólitos relacionados ao metabolismo energético e que a subalimentação, nesse experimento, foi suficiente para permitir que as fêmeas tivessem gestação saudável, e ainda relataram que animais dessa raça e criados nas mesmas condições que as fêmeas do experimento podem receber a alimentação estudada sem que ocorram prejuízos à saúde.

Sabe-se que a subnutrição causa sérios prejuízos a reprodução, baseado nisso, Sosa et al. (2009), estudaram o perfil metabólico de ovelhas da raça Aragonesa, que estavam divididas em 2 grupos, 11 receberam o total do requerimento, enquanto 13 receberam somente a metade. Foi feita a sincronização do cio e as fêmeas foram colocadas em cobertura. A cada 2 dias os animais tinham o sangue colhido e no dia $14^{\circ}$ do experimento foi realizado o ultrasom e verificado que no controle e no tratamento, respectivamente, havia 6 e 7 ovelhas gestantes. Neste mesmo dia todas as ovelhas do experimento foram eutanaziadas. Não houve efeito da gestação no ganho de peso e no escore corporal, mas as ovelhas subalimentadas apresentaram uma progressiva diminuição de peso, enquanto o outro grupo permaneceu estável. 
A glicemia não foi alterada pelo tratamento, os autores concluíram que no início da gestação pouca alteração metabólica ocorreu.

Obidike, Aka e Okafor (2009) objetivaram acompanhar as alterações hematológicas e bioquímicas de 12 ovelhas da raça West African Dwarf durante o terço final da gestação e lactação. Os autores não encontraram diferença nos valores do volume globular, contagem de eritrócitos, no volume corpuscular médio e na concentração de hemoglobina, quando compararam os valores sanguíneos pré-parto e pós-parto. A concentração de triglicérides e de creatinina apresentaram maiores valores com 10 dias do pós-parto do que no terço final da gestação, enquanto que a albumina plasmática teve menor valor no início da lactação quando se compara com os valores normais para a espécie. Os autores observaram que nesse trabalho houve mais alterações bioquímicas que hematológicas no período pósparto e relatam que mensurações sanguíneas são importantes para se verificar a saúde do rebanho.

Cardoso et al. (2010) descreveram mudanças do perfil metabólico de ovelhas da raça Santa Inês em diferentes tempos do periparto, criadas no estado do Rio de Janeiro. As concentrações de hemoglobina diminuíram entre os dias 20 e 30 pós parto, coincidente com o aumento do OPG. As concentrações de albumina sérica e uréia plasmática apresentaram equações de regressão lineares com decréscimo dos valores do pré-parto para o pós-parto. As equações de regressão para o beta-hidroxibutirato, apresentaram um comportamento quadrático e apresentaram valores mais elevados tanto nos dias que antecederam o parto, quanto nos que sucederam ao parto. Os autores concluíram que a concentração de hemoglobina foi o parâmetro mais sensível ao balanço metabólico negativo observado no pico de lactação; ovelhas da raça Santa Inês em condição corporal entre 3,0 e 2,5 no período do periparto são capazes de garantir parâmetros hematológicos compatíveis com a produção e saúde; valores baixos de albumina sérica e uréia plasmática evidenciaram um balanço proteico inadequado, não contemplando as necessidades nutricionais dos animais no periparto. 
Alguns estudos experimentais têm mostrado que ovelhas alimentadas com altas concentrações de proteína degradável no rúmen tem uma alta quantidade de uréia e amônia no plasma e no útero, o que pode alterar as taxas reprodutivas. Baseado nisso Karen et al. (2011) ofereceram uma dieta com o dobro da exigência de proteína preconizada pelo NRC, em 185 ovelhas que tinham entre 1-10 anos, AwassixMerino. As ovelhas foram inseminadas no dia 0 e no dia 80 , foi realizado o exame de ultrassonografia, pelo qual foi possível observar 38 ovelhas prenhes. As colheitas de sangue foram realizadas no dia 0 e 18 . Não houve diferença significativa na uréia plasmática entre as ovelhas prenhes e não prenhes, nas 2 colheitas realizadas. Entretanto, a uréia plasmática foi menor no dia 18, tanto para as ovelhas prenhes, quanto as não gestantes. Os autores concluíram que nesse experimento, devido ao alto número de ovelhas vazias não foi possível estabelecer uma relação entre taxa de prenhez com concentração de uréia plasmática.

Duehlmeier et al. (2011) estudaram as alterações metabólicas de ovelhas prenhes e lactantes que estavam divididas em 2 grupos: alto risco de terem Toxemia da Prenhez, com 6,5 anos e baixo risco, com 2,5 anos. Em contraste com as ovelhas mais velhas, que não apresentaram diferença no ganho de peso no decorrer da gestação e lactação, as ovelhas mais novas tiveram, no meio da gestação, um aumento de $49 \%$ no peso. A glicemia e a concentração de insulina foram menores no final da gestação, comparados com os valores obtidos na lactação. Em ambos os grupos, os níveis de $\square \square-$ hidroxibutirato foram elevados durante o final da gestação e lactação, quando se comparava com o período seco e início da gestação. Os autores concluíram que a ausência de ganho de peso significativo, aumento da lipólise e diminuição da secreção de insulina no final da gestação indica que este período requer maiores adaptações metabólicas em ovelhas mais velhas, que nas mais jovens, reforçando o que a literatura nos mostra.

\subsubsection{Perfil metabólico em ovelhas não prenhes}


Segundo Sartorelli et al. (2003), os animais de rebanho estão sempre expostos a fatores estressantes, que afetam o bem estar, a produção e reprodução, baseado nisso, os autores estudaram 4 ovelhas Charolle, não lactantes e não prenhes, as quais foram submetidas aos seguintes tratamentos: isoladas do rebanho por 1 hora e em seguida transportadas por 2 horas num caminhão, os animais do grupo controle foram submetidas ao estresse induzido com injeções de ACTH. As análises bioquímicas revelaram que o estresse natural e o induzido aumentaram o valor de cortisol, porém somente o estresse natural provocou um aumento na glicemia, de ácidos graxos não esterificados e aumento na concentração de beta- hidroxibutirato.

Ribeiro et al. (2003) utilizaram 30 borregas Corriedale com peso inicial de $10 \mathrm{~kg}$ e idade média de 4 meses mantidas em pastagens nativas do Rio Grande do Sul, para analisarem o perfil metabólico durante o período de 1 ano, objetivando pesquisar o comportamento dos parâmetros sanguíneos durante as estações. O sangue foi colhido com intervalos de três meses. Os metabólitos proteicos apresentaram diferenças entre estações, exceto albumina. O beta-hidroxibutirato teve maior valor no verão e mostrou-se relacionado com menor valor de glicose no mesmo período. A maioria dos metabólitos apresentou valores mais elevados na primavera, refletindo melhor oferta da forragem. No outono, foram observados valores compatíveis com déficit mineral e proteico. Os autores concluíram que no verão os valores obtidos sugerem que houve um déficit energético e que a realização do perfil metabólico deve ser utilizada no monitoramento de sistemas de produção ovina para a prevenção de patologias.

Ramin, Asri e Majdani (2005) avaliaram a concentração plasmática e a correlação entre glicose, beta-hidroxibutirato e uréia. Utilizaram 19 ovelhas secas saudáveis das raças Ghezel e Makuie de diferentes rebanhos que tinham idade de no máximo 4 anos. Os autores encontraram correlação negativa entre a glicemia e uréia, houve correlação positiva entre betahidroxibutirato e uréia, enquanto que não se observou correlação entre beta hidroxibutirato e glicose plasmática. Os autores concluíram que a presença de 
ORTUNHO, V.V. Revisão da literatura: mineralização e perfil metabólico em ovinos. PUBVET, Londrina, V. 7, N. 10, Ed. 233, Art. 1537, Maio, 2013.

parâmetros com correlação positiva em fêmeas secas pode ser útil para que se possa em estudos futuros observar as correlações em fêmeas prenhes para se estudar a Toxemia da Prenhez.

Sabendo-se que a alimentação pode influenciar a concentração dos metabólitos plasmáticos, Arai et al. (2007) estudaram 5 ovelhas Romney prenhes e pertencentes ao rebanho da Nova Zelândia alimentadas a pasto e estudaram 10 ovelhas não prenhes Suffolk residentes no Japão, onde o sistema de criação é o confinamento. Os autores não encontraram diferença na proteína total, glicose plasmática e no colesterol, porém os triglicérides foram estatisticamente menores nas residentes da Nova Zelândia.

Caldeira et al. (2007) realizaram um experimento para avaliar os efeitos da sub e supernutrição em 20 ovelhas não prenhes e não lactantes da raça Serra da Estrela no perfil metabólico com o objetivo de determinar possíveis alterações no status nutricional e metabólico desses animais. Amostras de sangue foram colhidas semanalmente por 72 semanas da seguinte maneira: dia 1 colheita às 9 da manhã e dia 2 às 16 horas. As ovelhas foram separadas em 4 grupos de acordo com o escore: grupo 1 escore 1,25; grupo 2 escore 2; grupo 3 escore 3 e grupo 4 escore 4 . Os animais dos grupos 1-3 receberam $200 \%$ do que é recomendado, enquanto o grupo 4 recebeu $30 \%$. A concentração de beta-hidroxibutirato permaneceu estável nos grupos 2 e 3, e diminuiu no grupo 1 logo quando a dieta foi implementada. Foi observada uma diminuição na concentração dos triglicérides durante a subnutrição. No grupo 4, a concentração de albumina no soro diminuiu gradualmente. Os autores concluíram que os resultados encontrados de glicose plasmática, ácido graxo não esterificado, albumina, uréia e concentração de insulina mostraram o status metabólico e nutricional dos animais e que seus resultados podem ser usados para prevenir desordens metabólicas.

Sabendo-se que animais submetidos ao estresse têm o seu desempenho comprometido, Mc Manus et al. (2009) pesquisaram a influência da temperatura nas ovelhas criadas no Brasil. Foram utilizadas 30 fêmeas 
secas Santa Inês, 10 Santa Inês x Bergamascia e 10 Bergamascia. Foram feitas 6 colheitas em dias diferentes e nestes dias eram realizadas 2 colheitas, uma de manhã e outra a tarde, entre o intervalo das colheitas os animais ficavam sob o sol, com água à vontade. Os valores de proteína total, número total de hemácias e hemoglobina, foram menores na Bergamascia, enquanto que a contagem de leucócitos e volume corpuscular médio não apresentaram diferenças entre as raças. Entre as duas colheitas foram observadas alterações nas aferições de temperatura, frequência cardíaca e respiratória. Os autores concluíram que os animais da raça Santa Inês foram os animais que menos sofreram com o estresse e mostraram-se mais adaptados ao clima do país.

Santana et al. (2009) relatam a importância de se determinar o perfil bioquímico e hematológico dos animais para que se possa prevenir patologias, baseado nisso os autores colheram amostras de sangue de 37 ovinos machos e 59 fêmeas, com 4 a 6 meses de idade, abatidos em um matadouro. Os autores verificaram que GGT e FA apresentaram-se maiores para os machos. Não foram observadas diferenças significativas entre os valores de AST, bilirrubina total, uréia, creatinina, contagens de hemácias e leucócitos, teores de hemoglobina e hematócrito, em função do sexo. Os autores concluíram que todos os resultados encontrados estavam dentro dos valores considerados normais para a espécie ovina, mostrando que os animais estavam saudáveis no abate.

Eshratkhah et al. (2010) estudaram 260 ovelhas Moghani saudáveis que estavam divididas em 4 grupos com idades diferentes, os autores analisaram o perfil lipêmico e encontraram que HDL e colesterol total foram menores em animais mais velhos.

Estudos relatam que o perfil lipêmico é alterado entre espécies e até mesmo interespécies, baseado nisso Eshratkhah et al. (2011) estudaram 96 ovelhas raça Iranian fat-tailed de diferentes idades para determinar o perfil lipêmico e determinar possíveis relações com o sexo e entre as diferentes idades dos animais. Os animais de 4-6 meses tiveram os menores valores de colesterol total, enquanto os que estavam com 1-3 meses apresentaram 
ORTUNHO, V.V. Revisão da literatura: mineralização e perfil metabólico em ovinos. PUBVET, Londrina, V. 7, N. 10, Ed. 233, Art. 1537, Maio, 2013.

maiores valores de colesterol HDL. Os valores de insulina, triglicérides e colesterol LDL não variaram entre as diferentes idades. Os autores encontraram correlação positiva entre triglicérides e HDL, colesterol total e triglicérides, colesterol total e HDL, correlações negativas foram encontradas entre HDL e LDL. Os autores concluíram que há diferenças entre as raças, idades, sexo, mudanças hormonais e dieta.

\section{REFERÊNCIAS}

ABDELRAHMAN, M. M. et al. The requirements of calcium by Awassi ewes at early lactation. Small Ruminant Research, Amsterdam, v. 45, p. 101-107, 2002.

ABDELRAHMAN, M.M. The effect of high calcium intake by pregnant Awassi ewes at late gestation on minerals status and performance of ewes and newborn lambs. Livestock Science, Amsterdam, v. 117, p. 15-23, 2008.

ACHMADI, J.; SANO, H.;TERASHIMA, Y. Effect of hypomagnesemia and cold exposure on tissue responsiveness to insulin in sheep given a low magnesium

and high potassium diet. Domestic Animal Endocrinology, Philadelphia, v. 20, p. 101-108, 2001.

AL-MUFARREJ., S. I. et al. Effect of chromium dietary supplementation on the imunne response and some blood biochemical parameters of transport- stressed lambs. Asian Australasian Journal Animal Science, Seoul, v. 21, p. 671-676, 2008.

ANTUNOVIĆ, Z. et al. Influence of the season and the reproductive status of ewes on blood parameters. Small Ruminant Research, Amsterdam, v. 4, p. 39-44,2002

ANTUNOVIĆ, D.; SENČIC, M.; SPERANDA, B. Influence of the season and the reproductive status of ewes on blood parameters. Small Ruminant Research, Amsterdam, v. 45, p. 3944, 2001.

ANDREWS, A. H.; HOLLAND-HOWES, V. E.; WILKINSON, J. I. D. Naturally occurring pregnancy toxaemia in the ewe and treatment with recombinant bovine somatotropin. Small Ruminant Research, Amsterdam, v. 23, p. 191-197,1996.

ARAI, T. et al.Comparison of plasma metabolite concentrations and peripheral leukocyte enzyme activities in sheep fed on different diets in New Zealand and Japan. Veterinary Research Communications, Dordrecht, v. 31, p. 681-684, 2007.

BALIKCI, E.; YILDIZ, A.; GÜRDOGAN, F. Blood metabolite concentrations during pregnancy and postpartum in Akkaraman ewes. Small Ruminant Research, Amsterdam, v. 67, p. 247251, 2007.

BARBOSA, O. R. et al. Zoneamento bioclimático da ovinocultura no Estado do Paraná. Revista Brasileira de Zootecnia, Viçosa, MG, v. 30, n. 2, p. 454-460, 2001.

BARBOSA, M. A. A.; OLIVEIRA, R. L. Bovinocultura de corte: desafios e tecnologias. Salvador: EDUFBA, 2007. 
BARUSELLI, M. S. Minerais orgânicos: o que são, como funcionam e vantagens do seu uso em ruminantes. In: SIMPÓSIO DE PECUÁRIA DE CORTE, 2., 2000, Botucatu. Anais... Botucatu: UNESP/FMVZ, 2000. p. 2-19.

BARUSELLI; M. S. Suplementos e co-produtos na nutrição de gado de corte. In:

BARBOSA, M. A. A., OLIVEIRA, R. L. Bovinocultura de corte: desafios e tecnologias. Salvador: EDUFBA, 2007. p. 15-49.

BARROS, N.N. et al. Saleiro: cocho para suplementação de caprinos e ovinos. Sobral: Embrapa, Dez. 2006. (Comunicado Técnico). ISSN 1676-7675. Disponível em: <http://www.infoteca.cnptia.embrapa.br/bitstream/CNPC/20246/1/cot70.pdf>. Acesso em: 6 jul. 2010.

BATAVANI, R. A.; ANSARI, M. H.; ASRI, S. Concentrations of serum total protein and protein fractions during diestrus and pregnancy in Makuii ewes. Comparative Clinical Pathology, Surrey, v. 15, p. 227-230, 2006.

BATHAEI, S. S.; LEROY, P. L. Note on age and body weight at puberty in Mehraban Iranian fattailed ewe lambs. Tropical Animal Health Production, Dordrecht, v. 29, p. 55-59, 1997.

BEITZ, D. C. Metabolismo dos carboidratos. In: REECE, W. O.; SWENSON, M. J. Fisiologia dos animais domésticos. 11. ed. Rio de Janeiro: Guanabara, 1996. p. 398-429.

BELL, A. W.; BAUMAN, D. E. Adaptations of glucose metabolism during pregnancy and lactation. Journal of Mammary Gland and Neoplasia, New York, v. 2, n. 3, p. 265-278, 1997.

BOLAND T.M. et al. The effects of mineral supplementation to ewes in late pregnancy on colostrum yield and immunoglobulin $G$ absorption in their lambs. Livestock Production Science, Dublin, v. 97, p. 141-150, 2005.

BOLAND, T. M. et al. The effects of cobalt and iodine supplementation of the pregnant ewe diet on immunoglobulin G, vitamin E, T3 and T4 levels in the progeny. Animal, Dublin, v. 2, p. 197-206, 2008.

BOUCINHAS, C. C. et al. Dinâmica do peso e da condição corporal e eficiência reprodutiva de ovelhas da raça Santa Inês e mestiças Santa Inês-Suffolk submetidas a dois sistemas de alimentação em intervalos entre partos de oito meses. Ciência Rural, Santa Maria, v. 36, n. 3, p. 904-909, maio-jun. 2006.

BRAUN, J. P.; TRUMEL, C.; BÉZILLE, P. Clinical biochemistry in sheep: A selected review. Small Ruminant Research, Amsterdam, v. 92, p. 10-18, 2010.

BRITO, A. M., et al. Composição do sangue e do leite em ovinos leiteiros do sul do Brasil: variações na gestação e na lactação. Ciência Rural, Santa Maria, v. 36, n. 3, p. 942-948, maio-jun. 2006.

BRUSS, M. L. Lipids and Ketones. In: KANEKO, J. J. Clinical biochemistry of domestic animals. 5. ed. New York: Academic Press, 1997. p. 45-81.

CALDEIRA, R. M. Monitorização da adequação do plano alimentar e do estado nutricional em ovelhas. Revista Portuguesa de Ciências Veterinárias, Lisboa. v. 100, p. 125-139, 2005.

CALDEIRA, R. M. et al. The effect of long-term feed restriction and over-nutrition on body condition score, blood metabolites and hormonal profiles in ewes. Small Ruminant Research, Amsterdam, v. 68, p. 242-255, 2007. 
CANOVA, E. B.; MOREIRA, H. L.Produção de carne ovina a pasto. PUBVET, Londrina, v. 3, n. 33, ed. 94, art. 666, 2009. Disponível em: <http://www.pubvet.com.br/artigos_det.asp?artigo=542>. Acesso em: 29 abr. 2010.

CARDOSO, E. C. et al . Peso e condição corporal, contagem de OPG e perfil metabólico sanguíneo de ovelhas da raça Santa Inês no periparto, criadas na região da Baixada Litorânea do Estado do Rio de Janeiro. Revista Brasileira de Ciências Veterinárias, Rio de Janeiro, v. 17, n. 2, p. 77-82, maio/ago. 2010.

CHADWICK, M.A.et al. Dietary exposure of pregnant ewes to salt dictates how their offspring respond to salt. Physiology \& Behavior, Austrália. v. 97, p. 437-445, 2009.

CHENG, J. et al. Effects of dietary copper source and level on metabolic hormones and lipogenic and lipolytic enzyme activities in lambs. Small Ruminant Research, Amsterdam, v. 89 p. 12-17, 2010.

CONTRERAS, P.; WITTWER, F.; BOHMWALD, H. Uso dos perfis metabólicos no monitoramento nutricional dos ovinos. In: GONZÁLEZ, F. H. D. Perfil metabólico em ruminantes: seu uso em nutrição e doenças nutricionais. Porto Alegre: UFRGS, 2000. p. 75-88.

DALLAGO, B. S.L. et al. Performance and ruminal protozoa in lambs with chromium supplementation. Research in Veterinary Science, Hannover, v. 90, n. 2, p. 253-256, 2011. doi:10.1016/j.rvsc.2010.06.015

DATTA, C.; MONDAL, M. K.; BISWAS, P. Influence of dietary inorganic and organic form of copper salt on performance, plasma lipids and nutrient utilization of Black Bengal (Capra hircus) goat kids. Animal Feed Science and Technology, Kolkata, v. 135, p. 191-207, 2007.

DAVIS, P. A. et al. Tolerance of inorganic selenium by range-type ewes during gestation and lactation. Journal of Animal Science, Louisiana, v. 84, p. 660-668, 2006.

DOMÍNGUEZ-VARA, I. A. et al. Effects of feeding selenium-yeast and chromium-yeast to finishing lambs on growth, carcass characteristics, and blood hormones and metabolites. Animal Feed Science and Technology, México, v. 152, p. 42-49, 2009.

DUEHLMEIER, R. et al. Metabolic adaptations to pregnancy and lactation in German Blackheaded Mutton and Finn sheep ewes with different susceptibilities to pregnancy toxaemia. Small Ruminant Research, Amsterdam, v. 96, p. 178-184, 2011.

ECKERT, G. E. et al. Copper status of ewes fed increasing amounts of copper from copper sulfate or copper proteinate. Journal of Animal Science, Louisiana, v. 77, p. 244-249, 1999.

EHRHARDT, R. A. et al. Maternal leptin is elevated during pregnancy in sheep Maternal leptin is elevated during pregnancy in sheep. Domestic Animal Endocrinology, New York, v. 21, p. 85-96, 2001.

EL-SHERIF, M. M. A.; ASSAD, F. Change in some blood constituints of Barki ewes during pregnancy and lactation under semi arid conditions. Small Ruminant Research, Amsterdam, v. 40, p.269-277, 2001.

ESHRATKHAH, B. et al. Relationship between the blood thyroid hormones and lipid profile in Moghani sheep; influence of age and sex. Comparative Clinical Pathology, Iran, v. 19, p.15-20, 2010. 
ESHRATKHAH, B. et al. Relationship between the level of plasma insulin and lipidprofile in Iranian fat-tailed sheep. Comparative Clinical Pathology, Iran, v. 20, n. 3, p. 223-226, 2011.

FARINATTI, et al. Desempenho de ovinos recebendo suplementos ou mantidos exclusivamente em pastagem de azevém (Lolium multiflorum Lam.) Revista Brasileira de Zootecnia, Viçosa, MG, v. 35, n. 2, p. 527-534, 2006.

FORBES, C. D. et al. Growth and metabolic characteristics of Suffolk and Gulf Coast Native yearling ewes supplemented with chromium tripicolinate. Small Ruminant Research, Amsterdam, v. 28, p. 149-160, 1998.

FUKAO, T.; LOPASCHUK, G. D.; MITCHEL, G.A. Pathways and control of ketone body metabolism: on the fringe of lipid biochemistry. Prostaglandins, Leukotrienes and Essential Fatty Acids, Montreal, v. 70, p. 243-251, 2004.

GARG, A. K.; MUDGAL, V.; DASS, R. S. Effect of organic zinc supplementation on growth, nutrient utilization and mineral profile in lambs. Animal Feed Science and Technology, México, v. 144, p. 82-96, 2008.

GERASSEEV, L. C. et al. Efeitos das restrições pré e pós-natal sobre o crescimento e desempenho de cordeiros Santa Inês do desmame ao abate. Revista Brasileira de Zootecnia, Viçosa, MG, v. 35, n. 1, p. 237-244, 2006.

GIADINIS, N. D. et al. Selenium, vitamin E and vitamin A blood concentrations in dairy sheep flocks with increased or low clinical mastitis incidence. Small Ruminant Research, Amsterdam, v. 95, p.193-196, 2011.

GONZÁLEZ, F. H. D. Uso do perfil metabólico para determinar o status nutricional em gado de corte. In: GONZÁLEZ, F. H. D. et al. (Eds.). Perfil metabólico em ruminantes: seu uso em nutrição e doenças nutricionais. Porto Alegre: UFRGS, 2000. p. 63-74.

GONZÁLEZ, F. H. D., SCHEFFER, J. F. S. Perfil sanguíneo: ferramenta de análise clínica, metabólica e nutricional. In: GONZÁLEZ, F. H. D.; CAMPOS, R. (Eds.). Anais do I Simpósio de Patologia Clínica Veterinária da Região Sul do Brasil. Porto Alegre: Gráfica da Universidade Federal do Rio Grande do Sul, 2003. p. 73-89.

GONZÁLEZ, F. H. D. et al. Coleta e manejo de amostras sanguíneas em bovinos. In: GONZÁLEZ, F. H. D. Uso de provas de campo e laboratório clínico em doenças metabólicas e ruminais de bovinos. Porto Alegre: Gráfica da Universidade Federal do Rio Grande do Sul, 2000. p. 9-12.

GRACE, N. D. The determination of mineral requirements of sheep and cattle. Procceeding of the New Zealand Society of Animal Production, Hamilton, v. 44, p. 139-141, 1984.

GUINAN, M. et al. The effect of timing of mineral supplementation of the ewe diet in late pregnancy on immunoglobulin $\mathrm{G}$ absorption by the lamb. Animal Science, New York, v. 80, p. 193-200, 2005.

GUNTER, S. A. et al, Digesta kinetics, ruminal fermentation characteristics and serum metabolites of pregnant and lactating ewes fed chopped alfalfa hay. Journal of Animal Science, Louisiana, v. 68, p. 3821-3831, 1990.

HALL, J. A. et al. Comparison of selenium status in sheep after short-term exposure to highselenium-fertilized forage or mineral supplement. Small Ruminant Research, Amsterdam, v. 82 , p. 40-45, 2009. 
HALL, J. A. et al. Organic and inorganic selenium: oral bioavailability in ewes. Journal Animal Science, USA, v. 90, p. 568-576, 2012a.

HALL, J. A. et al. Organic and inorganic selenium: II. Transfer efficiency from ewes to lambs. Journal Animal Science, USA, v. 90, p. 577-584, 2012b.

HAMILTON, T. R. S. Características seminais de ovinos alimentados com uréia e diferentes fontes de enxofre. 2006. Dissertação (Mestrado em Reprodução Animal)Faculdade de Medicina Veterinária e Zootecnia, São Paulo, 2006.

HARMEYER, J.; SCHLUMBOHM, C. Pregnancy impairs ketone body disposal in late gestating ewes: Implications for onset of pregnancy toxaemia. Research in Veterinary Science, Hannover, v. 81, p. 254-264, 2006.

HARMEYER, J.; SCHLUMBOHM, C. Twin-pregnancy increases susceptibility of ewes to hypoglycaemic stress and pregnancy toxaemia. Research in Veterinary Science, Hannover, v. 84 , p. 286-299, 2008.

HATFIELD, P. G. et al. Zinc and copper status in ewes supplemented with sulfate- and amino acid-complexed forms of zinc and copper. Journal of Animal Science, Louisiana, v. 79, p. 261-266, 2001.

HATFIELD, P. G. et al. Serum $a$-tocopherol and immune function in yearling ewes supplemented with zinc and vitamin E. Journal of Animal Science, Louisiana, v. 80, p. 1329-1334, 2002.

HENRY, P. R.; LITTELL, R. C.; AMMERMAN, C. B. Effect of high dietary zinc concentration and length of zinc feeding on feed intake and tissue zinc

concentration in sheep. Animal Feed Science Technology, v. 66, p. 237-245, 1997.

HOLWERDA, R. A.; ALBIN, R. C.; MADSEN, F. C. Chelation effectiveness of zinc proteinates demonstrated. Feedstuffs, Minneapolis, v. 19, p. 12-13, Jun. 1995.

HOMEM JUNIOR, A. C. et al. Ganho compensatório em cordeiras na fase de cria: desempenho e medidas biométricas. Revista Brasileira de Zootecnia, Viçosa, MG, v. 36, n. 1, p. 111$119,2007$.

HUSTED, S. M. et al. Glucose homeostasis and metabolic adaptation in the pregnant and lactating sheep are affected by the level of nutrition previously provided during her late fetal life. Domestic Animal Endocrinology, New York, v. 34, n. 4, p. 419-431, May 2008.

HOLANDA JUNIOR, E.V.; SÁ, J. L.; ARAÚJO, G. G. L. Articulação dos segmentos da cadeia produtiva de caprinos e ovinos os fluxos alternativos de comercialização. In: SIMPÓSIO INTERNACIONAL SOBRE CAPRINOS E OVINOS DE CORTE, 2.; SIMPÓSIO INTERNACIONAL SOBRE AGRONEGÓCIO DA CAPRINOCULTURA LEITEIRA, 1., 2003, João Pessoa. Anais... João Pessoa : $\quad$ EMEPA-PB, $2003 . \quad$ Disponível em: <http://www.infoteca.cnptia.embrapa.br/bitstream/CPATSA/27430/1/OPB988.pdf>.__Acesso em: 2 jun. 2010.

KABAKCI, N. et al. Pathological, clinical and biochemical investigation of naturally occuring pregnancy toxemia of sheep. Acta Veterinaria, Beograd, v. 53, n. 2-3, p. 161-169, 2003.

KANEKO, J. J. Carbohidrate Metabolism and its disease. In:

Clinical biochemistry of domestic animals. 5. ed. New York: Academic Press, 1997. p. 45-81. 
KAREN, A. M. et al. Plasma urea nitrogen in relation to pregnancy rate in dairy sheep. Animal Reproduction Science, Egypt, v. 124, p. 69-72, 2011.

KARAPEHLIVAN, M. et al. Blood biochemical parameters during the lactation and dry period in Tuj ewes. Small Ruminant Research, Amsterdam, v. 73, p. 267-271, 2007.

KHAN, Z. I. et al. Seasonal assessment of selenium as a hazardous element in pasture and animal system: a case study of Kajli sheep in Sargodha, Pakistan. Journal of Hazardous Materials, Paquistão, v. 179, p.1111-1114, 2010.

KELLOGG; D. W., KEGLEY, E. B. Feed supplements: organic-chelated minerals. In: FUQUAY, J. W. (Ed.). Encyclopedia of Dairy Science. London: Academic Press, 2002. p. 981-996.

KENT, J. E. Stress in transported sheep. Comparative Haematology International, Edimburg. v. 7, p. 163-166, 1997.

KESSABI, M. et al. experimental acute sodium fluoride poisoning in sheep: renal, hepatic, and metabolic effects. Fundamental and applied toxicology, France, v. 5, p. 1025-1033, 1985.

KITCHALONG, L. et al. Influence of chromium tripicolinate on glucose metabolism and nutrient partitioning in growing lambs. Journal of Animal Science, Louisiana, v. 73, p. 2694-2705, 1995.

KOJOURI, G. A.; SHIRAZI, A. Serum concentrations of $\mathrm{Cu}, \mathrm{Zn}, \mathrm{Fe}, \mathrm{Mo}$ and $\mathrm{Co}$ in newborn lambs following systemic administration of Vitamin $E$ and selenium to the pregnant ewes. Small Ruminant Research, Amsterdam, v. 70, p. 136-139, 2007.

LINDEMANN; M. D. Use of chromium as an animal feed supplement. In: VINCENT, J. B. (Ed.). The Nutritional Biochemistry of Chromium(III). Amsterdam: Elsevier, 2007. Cap. 5, p. 85-118.

LINDSAY, D. B. Ruminant metabolism in the last 100 years. Journal of Agricultural Science, Loughborough, v. 144, p. 205-219, 2006.

LOPES, S. T. A; BIONDO, A. W. ; SANTOS, A. P. Manual de Patologia Clínica Veterinária. 3. ed. Santa Maria, 2007. 107 p.

LUO; X.G. et al. Relative bioavailability of copper in a copper-lysine complex or copper sulfate for ruminants as affected by feeding regimen. Animal Feed Science Technology, Flórida, $v$. 57, p. 281-289, 1996.

MACEDO, V. P.; MACEDO, L. G. Principais causas de mortalidade de cordeiros: uma revisão. PUBVET, Londrina, v. 2, n. 16, Abr., 2008. Disponível em: <http://www.pubvet.com.br/texto.php?id=205>. Acesso em: 20 jun. 2008.

MATSUNOBU, S. et al. Insulin secretion and glucose uptake in hypomagnesemic sheep fed a low magnesium, high potassium diet. The Journal of Nutritional Biochemistry, New York, v.1, p. $167-171,1990$.

MAVROGIANNI, V. S.; BROZOS, C. Reflections on the causes and the diagnosis of periparturient losses of ewe. Small Ruminant Research, Amsterdam, v. 76, p. 77-82, 2008.

Mc MANUS, C. et al. Heat tolerance in Brazilian sheep: physiological and blood parameters. Tropical Animal Health and Production, Dordrecht, v. 41, n. 1, p. 95-101, 2009. 
MEDINA, I. M.; NATEL, S. A. O uso de suplementação para diferentes categorias. Piracicaba: MilkPoint, 2010. Disponível em: <http://www.farmpoint.com.br/o-uso-desuplementacao-para-diferentes-categorias_noticia_54299_3_28_.aspx>. Acesso em: 31 maio 2010.

MOHRI, M. et al. Parenteral selenium and vitamin E supplementation to lambs: hematology, serum biochemistry, performance, and relationship with other trace elements. Biological Trace Element Research, Iran, v. 139, p. 308-316, 2011.

MOHRI, M.; REZAPOOR, H. Effects of heparin, citrate, and EDTA on plasma biochemistry of sheep: Comparison with serum. Research in Veterinary Science, Hannover, v. 86, p. 111114, 2009.

MONTEMÓR, C. H. Desempenho e perfil metabólico de bovinos da raça nelore suplementados com cromo orgânico. 2005. Dissertação (Mestrado em Ciência Animal) Universidade Estadual de Londrina, Londrina, 2005.

MORAES, S. S. Elementos minerais quelatados em suplementos para bovinos de corte. In: CURSO SOBRE SUPLEMENTAÇÃO MINERAL EM BOVINOS, 3., 2000, Campo Grande. Compilação dos trabalhos apresentados. Campo Grande: Embrapa Gado de Corte, 2000. p. 62-66.

MOSTAFA-TEHRANI, A. et al. Non-carcass components and wholesale cuts of Iranian fat-tailed lambs fed chromium nicotinate or chromium chloride. Small Ruminant Research, Amsterdam, v. 63, p. 12-19, 2006.

MUNÕZ, C. et al. Nutritional status of adult ewes during early and mid- pregnancy: effects of supplementation with selenised yeast on ewe reproduction and offspring performance to weaning. Animal, Dublin, v. 2, p. 64-72, 2008.

MURILlO, M. D.; PLAZA, M. A.; ARRUEBO, M. P. The Effect of $\mathrm{Mn}^{2+}, \mathrm{Zn}^{2+}, \mathrm{Ba}^{2+}$ and $\mathrm{Ca}^{2+}$ on Spontaneous Motility in Sheep Duodenum in vitro. General Pharmacology, Spain, v. 28, $\mathrm{n}$. 1, p. 65-71, 1997.

NASCIMENTO, S. Caprinos e ovinos, tendências 2012. Globo Rural, Rio de Janeiro, Globo, n. 315. p. 44, 2012.

OBIDIKE, I. R.; AKA, L. O.; OKAFOR, C. I. Time-dependant peri-partum haematological, biochemical and rectal temperature changes in West African dwarf ewes. Small Ruminant Research, Amsterdam, v. 82, p. 53-57, 2009.

OLSON, K. C. Management of mineral supplementation programs for cow-calf operations. Veterinary Clinics of North America: Food Animal Practice, Maryland Heights, v. 23, p. 69-90, 2007.

ORTOLANI, E. L. Toxemia da prenhez em pequenos ruminantes: como reconhecê-la e evita-la. [S.I.]: Monografias.com, 2009. Disponível em:

<http://br.monografias.com/trabalhos901/toxemia-prenhez-ruminantes/toxemia-prenhezruminantes.shtml>. Acesso em: 25 ago. 2009.

OSORIO, M. T. et al. Effect of ewe's milk versus milk-replacer rearing on mineral composition of suckling lamb meat and liver. Small Ruminant Research, Amsterdam, v. 68, p. 296-302, 2007.

PAL, D. T. et al. Effect of copper- and zinc-methionine supplementation on bioavailability, mineral status and tissue concentrations of copper and zinc in ewes. Journal of Trace Elements in Medicine and Biology, India, v. 24, p. 89-94, 2010. 
PALMQUIST, D. L.; MATOS, W. R. S. Metabolismo de lipídeos. In: BERCHIELLI, T. T.; PIRES, A.; OLIVEIRA, S. G. Nutrição de Ruminantes. Jaboticabal: Funep, 2006.

PASTOR, J.; LOSTE, A.; SÁEZ, T. La toxemia de gestación en la Oveja. Pequeños Ruminantes, [s.I.], v. 2, n. 3, p. 18-24, 2001.

PECHOVA, A. et al. The influence of supplementation of different forms of zinc in goats on the zinc concentration in blood plasma and milk. Biological Trace Elements Research, Czech Republic, v. 132, n. 1-3, p. 112-121, 2009.

PEDREIRA, M. S.; BeRCHIELLI, T. T. Minerais. In: BERCHIELLI, T. T.; PIRES, A.; OliVeIRA, S. G. Nutrição de Ruminantes. Jaboticabal: Funep, 2006.

PEIXOTO, P. V. et al. Princípios de suplementação mineral em ruminantes. Pesquisa Veterinária Brasileira, Rio de Janeiro, v. 25, ed. 3, p.195-200, 2005.

PETHICK, D. W.; LINDSAY, D. B. Metabolism of ketone bodies in pregnant sheep. The British Journal of Nutrition, Cambridge, v. 48, p. 549-564, 1982.

PILAR, R. C.; PEREZ, J.; SANTOS, C. L. Manejo reprodutivo da ovelha recomendações para uma parição a cada 8 meses. Lavras: UFLA, 2002. 32 p. (Boletim Técnico, v. 50).

PLESSIS, S. S.; VAN NIEKERK, F. E.; COETZER, W. A. The effect of dietary molybdenum and sulphate on sexual activity. Small Ruminant Research, Amsterdam, v. 33, p. 71-76, 1999.

POLIZOPOULOU, Z. S. Haematological tests in sheep health management. Small Ruminant Research, Amsterdam, v. 92, p. 88-91, 2010.

POTTER, B. J. et al. Restoration of brain growth in fetal sheep after iodized oil administration to pregnant iodine-deficient ewes. Journal of the Neurological Sciences, Australia, v. 66, p. 15-26, 1984.

RAJARATNE, A. A. J. et al. The effect of variation in dietary protein or mineral supply on calcium and phosphorus metabolism in lactating ewes. British Journal of Nutrition, Aberdeen, v. 64, p. 147-160, 1990.

RAMIN, A. G.; ASRI, S.; MAJDANI, R. Correlations among serum glucose, betahydroxybutyrate and urea concentrations in non-pregnant ewes. Small Ruminant Research, Amsterdam, v. 57, p. 265-269, 2005.

RESENDE, T. K. et al. Exigências de minerais para cabras SRD durante a gestação: cálcio e fósforo. Revista Brasileira de Zootecnia, Viçosa, MG, v. 28, n. 6, p.1397-1402, 1999.

RIBEIRO, L. A. O. et al. Perfil metabólico de borregas Corriedale em pastagem nativa do Rio Grande do Sul. Acta Scientiae Veterinariae, Santa Maria, v. 31, p. 167-170, 2003.

RIBEIRO, L. A. O. Perfil metabólico de ovelhas Border Leicester X Texel durante a gestação e a lactação. Revista Portuguesa de Ciências Veterinárias, Lisboa, v. 99, p. 155-159, 2004.

RICCÓ, D. Indicadores sanguíneos e corporais de avaliação metabólico-nutricional em ruminantes. 2004. 13 f. Seminário (Pós-Graduação em Ciências Veterinárias) - Universidade Federal do Rio Grande do Sul, Porto Alegre, 2004. Disponível em: <http://www6.ufrgs.br/bioquimica/posgrad/BTA/perfil_ruminantes.pdf>. Acesso em: 30 abr. 2008. 
RIGHI, A. A ovinocultura como alternativa de bons rendimentos.CCR notícias, Santa Maria, 2005.

ROSA, G. T. et al. Influência da suplementação no pré-parto e da idade de desmama sobre o desempenho de cordeiros terminados em confinamento. Revista Brasileira de Zootecnia, $v$. 36, n. 4, p. 953-959, 2007.

RUSSEL, K. E.; ROUSSEL, A. J. Evaluation of the ruminant serum chemistry profile. Veterinary Clinical Food Animal, Texas, v. 23, p. 403-426, 2007.

SALEM, I. B. et al. Live weight and metabolic changes and the associated reproductive performance in Maiden ewes. Small Ruminant Research, Amsterdam, v. 81, p. 70-74, 2009.

SANSON, R. M. M.; MOMBACH, M. A.; SANTOS, S. F. Suplementação mineral para fêmeas caprinas e ovinas lactantes. Piracicaba: FarmPoint, 2010. Disponível em: <http://www.farmpoint.com.br/suplementacao-mineral-para-femeas-caprinas-e-ovinaslactantes_noticia_62422_3_28_.aspx>. Acesso em 1 jun. 2010.

SANTANA; A. M. et al. Hemograma e perfil bioquímico sérico de ovinos em idade de abate. Ciência Animal Brasileira, Goiás, Supl. 1, 2009.

SARGISON, N. D. et al. Plasma enzymes and metabolites as potential prognostic indices of ovine Pregnancy Toxaemia--a preliminary study. British Veterinary Journal, Oxford, v. 150, p. 271-278, 1994.

SARTORELLI, P. et al. The effect of natural and pharmacological stressors on sheep: haematological, biochemical and granulocytic functional changes. Veterinary Research Communications, Dordrecht, v. 27, suppl. 1, p. 723-726, 2003.

SCHEAFFER, A. N. et al. The effect of dietary restriction, pregnancy, and fetal type in different ewe types on fetal weight, maternal body weight, and visceral organ mass in ewes. Journal of Animal Science, Louisiana, v. 82, p.1826-1838, 2004.

SCHLUMBOHM, C.; HARMEYER, J. Pregnancy impairs ketone body disposal in late gestating ewes: Implications for onset of pregnancy toxaemia. Research in Veterinary Science, Hannover , v. 81, p. 254-264, 2006.

SCHLUMBOHM, C.; HARMEYER, J. Twin-pregnancy increases susceptibility of ewes to hypoglycaemic stress and pregnancy toxaemia. Hannover, v. 84, p. 286-299, 2008.

SILVA, A. E. D. F.; SILVA, M. U. D. Conceitos de higiene no manejo perinatal da criação caprina. Sobral: Embrapa - CNPC, 1983.

SORIO, A. Carne ovina e caprina: produção e consumo no Brasil e nas Américas. Piracicaba: FarmPoint, 2010. Disponível em: <http://www.farmpoint.com.br/carne-ovina-ecaprina-producao-e-consumo-no-brasil-e-nas-americas_noticia_62919_1_2_.aspx>. Acesso em: 1 jun. 2010.

SOSA, C. et al. Early pregnancy alters the metabolic responses to restricted nutrition in sheep. Domestic Animal Endocrinology, New York, v. 36, p. 13-23, 2009.

SOUZA, D. A. Carne ovina importada: volume, valores e perfil. Piracicaba: FarmPoint, 2010. Disponível em: <http://www.farmpoint.com.br/carne-ovina-importada-volume-valores-eperfil_noticia_62396_1_2_.aspx>. Acesso em: 28 maio 2010.

SOUZA, E.10 práticas sustentáveis. Globo Rural, São Paulo, n. 312, p. 36-37, out. 2011. 
SPEARS, J. W. Organic trace minerals in ruminant nutrition. Animal Feed Science and Technology, Amsterdam, v. 58, n. 1/2, p. 151-163, 1996.

SPEARS, J. W. Trace mineral bioavailability in ruminants. Journal of Nutrition, Bethesda, $v$. 133 , p. $1506-1509,2003$

SUTTLE, N. F. Mineral nutrition of livestock. 4. ed. Wallingford: CABI, 2010.

TANAKA, Y. et al. Plasma metabolite concentrations and hepatic enzyme activities in pregnant Romney ewes with restricted feeding. Research in Veterinary Science, Hannover, v. 85, p. 17-21. 2008.

TIBBO, M. et al. Factors affecting haematological profiles in three indigenous Ethiopian sheep breeds. Compedendiun Clinical Pathologic, London, v. 13, p. 119-127, 2005.

VECHI, J. B. A Criação de ovinos em Mato Grosso: uma alternativa para o ingresso de pequenos e médios produtores rurais na atividade. Cuiabá: Sedraf, 2010. Disponível em: <http://www.seder.mt.gov.br/arquivos/A_c8e35ceb0ca8142aaaff2f55be2c4114CRIACAO_OVI NOS_PROPOSTA_3.doc>. Acesso em: 28 abril 2010.

VIANA, D. F. Alguns aspectos da toxemia da prenhez em pequenos

ruminantes. 2001. Monografia (Medicina Veterinária) - Universidade Estadual da Bahia, Salvador, 2001.

VIANA, J. G. A. Panorama geral da ovinocultura no mundo e no Brasil. Revista Ovinos, Porto Alegre, ano 4, $\mathrm{n}$. 12, 2008.2 Disponível em: <www.almanaquedocampo.com.br/imagens/files/panorama\%20geral\%20ovinocultura\%20bra sil.pdf>. Acesso em: 16 abr. 2012.

VIANA, R. B. et al. Influência da gestação e do puerpério sobre o leucograma de caprinos da raça Saanen, criados no Estado de São Paulo. Brazilian Journal Veterinarian Research Animal Science, São Paulo, v. 39, n.4, p. 196-201, 2002.

VIÑOLES, C. et al. Short-term nutritional supplementation of ewes in low body condition affects follicle development due to an increase in glucose and metabolic hormones. Reproduction Research, Uruguay, v. 129, p. 299-309, 2005.

VONNAHME, K. A. et al. Impacts of maternal selenium and nutritional level on growth, adiposity, and glucose tolerance in female offspring in sheep. Domestic Animal Endocrinology, New York, v. 39, n. 4, p. 240-248, 2010

WANG, R. L. et al. Influence of dietary cobalt on performance, nutrient digestibility and plasma metabolites in lambs. Animal Feed Science and Technology, Amsterdam, v. 135, p. 346352, 2007.

WHITE, C. L.et al. Effects of copper and molybdenum supplements on the copper and selenium status of pregnant ewes and lambs. Journal Animal of Science, Wiscosin, v. 67, p. 803-809, 1989.

WILLIANS, C. C. et al. Glucose metabolism and insulin sensitivity in Gulf Coast Native and Suffolk ewes during late gestation and early lactation. Small Ruminant Research, Amsterdam, v. 54, p. 167-171, 2004.

WITTNER, F. Diagnóstico dos desequilíbrios metabólicos de energia em rebanhos bovinos. In: GONZALEZ, F. H. D. et al. Perfil Metabólico em ruminantes: seu uso em nutrição e doenças nutricionais. Porto Alegre: UFRGS, 2000. p. 9-22. 
XIAOGANG, Y. et al. Effects of chromium yeast on performance, insulin activity, and lipid metabolism in lambs fed different dietary protein levels. Asian Australian Journal of Animal Sciences, Louisiana, v. 21, n. 6, p. 853-860, 2008.

YARIM, G. F.; CIFTCI, G. Serum protein pattern in ewe with pregnancy toxemia. Veterinary Research Communications, Dordrecht, v. 33, p. 431-438, 2009. 